\title{
Heavy Rainfall at the SRS in July, August and October of $1990^{(\mathrm{U})}$
}

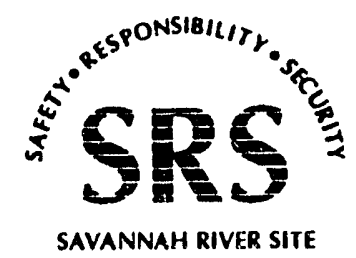

Prepared for the U. S. Department of Energy under contract No. DE-AC09-89SR18035 
This report was prepared by the Westinghouse Savannah River Company (WSRC) for the United States Department of Energy under Contract No. DE-AC09-89SR18035 and is an account of work performed under that contract. Neither the United States Department of Energy, nor WSRC, nor any of their employees make any warranty, expressed or implied, nor assume any legal liability or responsibility for the accuracy, completeness, or usefulness, of any information, apparatus, or product or process disclosed herein or represents that its use will not infringe privately owned rights. Reference herein to any specific commercial product, process, or service by trademark, name, manufacturer, or otherwise does not necessarily constitute or imply endorsement, recommendation, or favoring of the same by WSRC or by the United States Government or any agency thereof. The views and opinions of the authors expressed herein do not necessarily state or reflect those of the U.S. Government or any agency thereof.

This report has been reproduced directly from the best available copy

Available to DOE and DOE Contractors from the Office of Scientific and Technical Information, P..O. Box 62,

Oak Ridge TN 37831;

Prices available from

(615) $576-8401$

FTS 626-8401

Available to the public from the National Technical Information Service,

U.S. Department of Commerce

5285 Port Royal Road

Springfield VA 22161 


\section{Heavy Rainfall at the SRS in July, August and October of $1990^{(U)}$}

R.P. Addis and R.J. Kurzeja

Westinghouse Savannah River Company

Savannah River Site

Aiken, SC 29808 


\title{
Heavy Rainfall at the SRS in July, August and October of 1990
}

\author{
R. P. Addis and R. J. Kurzeja \\ Westinghouse Savarinah River Company \\ Savannah River Site \\ Aiken, SC 29808
}

\section{Executive Summary}

The Savannah River Site experienced intense periods of rainfall on July 25, August 22, October 10-12, and October $22-23,1990$.

The July 25 rainfall inundated the 700 area with 5.2 inches of rain during a threc-hour period flooding the basement of building 773-A. A statistical analysis indicated that this rainfall event has a recurrence interval of over 100 years.

The August 22 rainfall totaled 4.97 inches during a three-hour period at the SRS Climatology Site (in the center of the SRS) and 7.39 inches for a 12-hour period. This rainfall exceeded the 100-year recurrence interval for 3 and 12-hour duration.

The October 10-12 rainfall occurred during the passage of two tropical storms, Klaus and Marco, within a 48-hour period. Although these storms were not as iniense as the ones in July and August, they caused a 48-hour rainfa il amount that exceeded the $100-y r$ storm amount at several locations.

The October 22-23 rainfall was due to the passage of a cold front and caused rainfall at the SRS of approximately 5 inches over a 12-hour period. This rainfall and that of October 10-12 resulted in the wettest month in SRS history.

This report compares the rainfall from these storms with previous storms and with the 100-year rainfall estimates.

\section{Introduction}

Extreme rainfall can have a significant impact on SRS day to day operation and must also be considered for the planning and design of new facilities. Rainfall extremes are most commonly reported in terms of 24-hour periods, but heavy rain in a shorter period is also important because of the increased possibility of flooding. In addition, the a real extent of heavy rainfall can affect runoff rates.

In 1990 several heavy rainfalls occurred at the SRS. One in July flooded the basement of the 773-A building. Another in August caused heavy rainfall for durations of 30 ninutes to 12 hours. A third in October resulted in extreme rainfall over a 48 hour period.

The purpose of this report is to document the weather conditions and rainfall characteristics of three heavy rainfalls in 1990. The hope is that an understanding of past events will aid in the appreciation and planning of future extreme rainfalls.

Most of the information for this report came from the SRS rain gage network, which is shown in Fig. 1 and listed in Table 1. Most of the SRS gages are wedge-shaped plastic gages with larger cross-sections at the top than the bottom to amplify low rainfall readings. They have capacities of $\sim 6.2$ inches which are read and emptied each morning at 6:00 am. The gages at the Interim Waste Technology and Central Climatology sites are tipping-bucket types with unlimited capacity. Data from the Central Climatology gage is available every 15 minutes which allows the time history of rainfall to be documented. Data from Bush Field in Augusta is recorded every morning at 7:00 am. The instrument shelter near Building 773-A is checked at $~ 9: 00$ am. The difference in recording times explains why daily rainfall rates from nearby gages can differ significantly, particularly during periods of heavy rainfall. 
Rainfall rates at the SRS can also be inferred from the Bush Field radar. The advantage of radar is the ability to estimate the spatial and temporal variation of rainfall. Unfortunately, exact rainfall rates cannot be determined.

Rainfall information can also be obtained from personal observation. This is useful when the time period of heavy rainfall is in question. However, personal observation of rainfall amounts is often inaccurate.

\section{The storm of July 25,1990}

During the evening of Wednesday, July 25 a weak high pressure ridge extended over the southeastern United States behind a cold front that lay off the South Carolina coast. (See Fig. 2 and 3.) The cold front had passed through the SRS the previous day (Tuesday July 24) moving from northwest to the southeast. Scattered showers and thunderstorms developed during the afternoon of Wednesday July 25 throughout South Carolina and Georgia. None of the storms were exceptional in severity or organization.

National Weather Service weather radar summaries showed that by 4:00 pm EDT on the July 25 a loosely organized line of storms was located northwest of Augusta, GA, oriented northeast to southwest, traveling slowly towards the southeast (Fig. 4). The radar summaries are composites including data in Georgia from stations in Augusta, Atlanta, Macon, Waycross, Savannah and in South Carolina from Columbia and Charleston.

The radar showed that between 8:00 pm and 9:00 pm the most intense rainfall moved from north of Augusta to northeast of the SRS (Fig. 5). Although rainfall rates cannot be determined exactly from radar echoes, the echoes can be used to infer approximate rates. The radar echoes between 8:00 and 9:00 pm suggest a rainfall rate in the range 2.2 to 4.5 inches per hour over the SRS. These implied rainfall rates are not excessive - stronger radar signals are frequently observed. By 10:00 pm the sturms were dissipating with only light rainfall at SRS (Fig. 6). By 11:00 pm they were no longer detected by radar.

Rainfall data for July 25 is shown in Table 1 . This table shows the rainfall at SRS rain gage locations shown in Fig. 1. Table 1 shows that the 700 Area gages recorded rainfall of 4.5 and 5.4 inches, whereas the other Site gages recorded less than 2.5 inches. This suggests the storm was centered north of the Site.

Although the rain gage at the 773-A meteorological shelter measured 5.40 inches of rain for the 24-hour period ending the morning of the July 26, technicians from the Environ- mental Transport Group were on duty the previous evening during the storm and observed that virtually all of the rain occurred between 7:00 pm and 10:00 pm. Although a brief shower occurred shortly before 7:00 p.m, it was estimated to account for less than 1/10 inch of rain. A similar amount was estimated to fall after 10:00 pm. Thus, of the 5.4 inches measured, at least 5.2 inches is believed to have occurred between 7:00 pm and 10:00 pm. The timing of the rain is consistent with that recorded at the Central Climatology Site, where a total of 1.91 inches of rain fell between 7:00 and 10:00 pm. (Sec Figure 7)

Fire Protection personnel also measure rainfall daily in the 700 area. The personnel on duty Wednesday evening reported that all of the 24-hour total of 4.5 inches fell in 45 minutes. Although it is certainly possible that all 4.5 inches fell in 45 minutes, it is more likely, given the radar signals and conditions observed at 773-A, that the rain was spread over three hours, with a very intense 45 minute period.

\section{The storm of August 22, 1990}

On August 22 several thunderstorm cells brought heavy precipitation to the center of the SRS. Three cells moved over the site between midnight and 4:00 am and another one at 10:00 am in the morning. The weather pattern on this day was similar to that of July 25 except that on the 22 nd a weak high pressure center was located over the northeast US and the stationary front was to the north of the SRS (Fig. 8). These conditions persisted uni! Thursday August 23.

The rainfall data for the 24-hour periods ending at 6:00 am on August 22 and 23 are given in Table 1. This table shows rainfall measured at $-6: 00$ am on each day. Based on the time history of rainfall available from the SRS Climatology Site we conclude that these two 24-hour records represent rainfall in the early moming (before 7:00 am) and late moming (after 7:00 am) of August 22.

As can be seen from Table 1, two rain gages, at the 200-F and 200-H areas, received over 6 inches of rain on August 22. Since the gages hold a maximum of 6.2 inches, it is possible that more rainfall actually occurred at these sites. However, it is unlikely that the rainfall was much greater than 6 inches since the tipp: 6 -bucket gage at the Interim Waste Technology site, located within 1.5 miles of the F and $\mathrm{H}$ gages, recorded 5.81 inches. The SRS Climatology Site, which also has a tipping-bucket recording gage with unlimited capacity, received 5.78 inches of rain during this period.

The spatial distribution for the first rain period is shown in Figure 9. This figure shows rainfall amounts exceeding 6 
inches over an area of 9 square miles and exceeding 4 inches over half the site. Rainfall amounts at the site boundary were between 1 and 3 inches.

The time history of the rainfall can be seen in Fig. 10, which shows rainfall amounts in 15 minutes increments at the Climatology Site between midnight and 5:00 am. Three periods of heavy rain can be identified - one at 12:30 am, a second at 2:15 am, and a third at 3:30 am.

Another storm caused heavy rain in the center of the SRS the following morning between 9:30 and 11:00 am. The rainfall amounts for this shower are shown in Table 1 and Figure 11. Rainfall for this shower exceeded 1.5 inches near the site center. The time history of the rainfall at the Climatology Site is shown in Fig. 12.

\section{The storms of October 10-12, 1990}

The synoptic situation for October 10-12 is shown in Figs. 13-15. On October 10 a cold front was approaching SRS from the west, the remnants of tropical storm Klaus were located over South Carolina and tropical storm Marco was approaching from the south. These storms, although weakening at this time, nevertheless generated a continuous flow of moist tropical air over the Southeast US.

Despite the proximity of the cold front to South Carolina on October 10 , it did not contribute significantly to the heavy rains that fell at the SRS. This can be seen from Fig. 13 which shows very little rain near the front in the Southeast US. Instead, the 5+ inches of rain recorded at the Climatology Site on October 10 (Figure 17) is attributable to Klaus.

On the morning of October 11 the rain associated with Klaus had moved northeast of the SRS while Marco was located over central Florida (Figure 14). As a result, SRS did not experience any rain during the moming and afternoon of the October 11. At 3:00 pm EST an infrared satellite picture showed that Marco had moved to just south of the Georgia-Florida border (Fig 16). By evening Marco had moved north ward to a position over the SRS causing $\sim 1$ inch of rain by midnight. Over 3 additional inches of rain fell the following morning before Marco moved north of SRS.

Both Klaus and Marco were guided by an upper-level trough of low pressure centered over the Miss issippi Valley. As mentioned above, this trough did not bring significant rain to the Southeast but did provide the southwesterly steering winds that guided Klaus and Marco along roughly the same path. If this trough had been deeper and more moist, the rainfall at SRS might have been even greater than it was. However, such a possibility is remote since the synoptic pattern on October 10-12 is normal in Fall, i.e., midlatitude weather systems generally bring cool air but little rain to the Southeast.

Rainfall amounts are given in Table 1. For the 24-hour period ending at 7:00 am on October 11 rainfall ranged from 3.65 inches to 7.15 inches. On October 12 reported rainfalls were between 1.50 and 7.50 inches and on October 13, between 1.09 and 5.50 inches. The rain gages located at the barricades and Areas have capacities of 6.2 inches. Therefore, a rainfall of greater than 6.2 inches can only be recorded if the gage is emptied prior to the reading time of 6:00 am. It is not certain if this procedure is followed in all cases so reports exceeding 6.2 inches at the Areas and Barricades must be viewed with caution.

The largest rainfall, 7.50 inches, was seen at Bush Field. The Bush Ficld value includes a substantial amount that fell just before the 7:00 am reading time. SRS gages also recorded significant rainfall from this event but just after 7:00 am (see Fig. 17).

A time history of the rainfall at the Climatology Site is shown in Fig 17. The amounts are in hourly intervals except between 8:00 am and 12:00 noon on October 10, for which only a 4-hour value is available. The rain periods attributable to Klaus and Marco are clearly visible in the gage data.

\section{Rainfall of October 22-23}

The synoptic situation on October 22 and October 23 is shown in Figs. 18 and 19. The cold front seen at the Mississippi-Alabama border in Fig 18 passed through the SRS on the night of October 22. The rain began at 5:00 pm on October 22 and continued until 8:00 am on October 23.

The front produced moderate rainfalls in the Mississippi valley (generally less than 1 inch) but greater amounts as it moved into the Carolina's where rainfalls between 2 and 4 inches were seen. Rainfalls at the SRS were between 4 and 6 inches (Table 1) and were approximately double the 2.16 inches observed at Augusta's Bush field.

Fig. 20 shows the history of rainfall at the Climatology Site between 11:00 pm on October 22 and 5:00 am on October 23 when 3.37 inches of rain fell. (Approximately a half-inch of rain fell in the 6 hours preceding this period and another half-inch in the four hours afterwards.)

Although rainfall rates exceeding one inch per hour are normally associated with thunderstorms, this explanation 
does not apply to the heavy rains between 12:45 and 2:00 am on October 23. Bush Field in Augusta reported rain showers during this period but no thunder. In addition, the SRS wind towers reported light, slowly-varying winds instead of the strong, gusty winds seen in thunderstorms.

The reason for the high rainfalls at the SRS compared with surrounding areas was the formation of a mesoscale low pressure center at approximately midnight on October 22. This low pressure area can be seen on the North Carolina coast at 8:00 am on October 23 (Fig. 19). Analysis of the SRS $61 \mathrm{~m}$ tower data showed a low-level convergence zone over the SRS between 12:30 and 2:00 am on October 23, which accounts for the heavy rains at that time (Fig. 20). Apparently, Bush Field was on the western edge of this convergence zone, which explains the much lower rainfall recorded there.

The approximately 5 inches of rainfall measured from this storm is even more significant when added to the high rainfall experienced earlier in the month. The total rainfall for the month of October 1990 at the SRS ranged from 17.12 inches (at the 400-D area) to 19.05 inches (at Barricade 2), which ranks this month as the wettest ever recorded at the site!

\section{Rainfall statistics}

There are three methods for comparing a given rainfall to the maximum rainfall possible for a location:

(1) examination of local historical records,

(2) comparison with the probability of recurrence (PR)

(3) comparison with the probability of maximum precipitation (PMP).

Daily rainfall measurements have been made at SRTC since April 1, 1968. However, hourly data was not available before 1991. The Bush Field Airport in Augusta, GA has recorded hourly rainfall data from the beginning of the century. A complete hourly data base of Bush Field observations is available from August 1948 to May 1988 (Table 2). The largest hourly rainfall measured at Bush Field was 3.14 inches in July 1986. Rainfall data from the Columbia SC airport is also available from 1948 and the extremes are shown in Table 3. The maximum hourly rainfall was 3.80 inches in August 1965. In contrast, the largest hourly rainfall at SRS in 1990 was 2.45 inches, at the Climatology Site on August 22.

The largest 3-hour rainfall at Bush Field between 1948 and 1988 was 4.2 inches in September of 1975 . The largest at the Columbia airport was 5.03 inches in 1965. In 1990 SRS received 5.2 inches (estimated) in a three hour period on July 25 and 4.97 inches on August 22. These values exceed the Bush Field maximum and are comparable to that recorded at Columbia.

The maximum rainfall in a 24 hour period recorded at SRS prior to 1990 was 6.48 inches in May of 1986. Correspcinding records are 9.82 inches in 1929 for Bush Field and 7.66 inches in 1949 for the Columbia airport. The new record for SRS is 7.39 inches at the Climatology Site on August 22, 1990.

A second measure of rainfall extremes is the probability of recurrence (PR). This is a statistical variable based on historical rainfall rates for the U.S. The extreme values for various time periods interpolated for the Savannah River Site are given in Table 4. Also shown in this table are rainfall rates for July 25, August 22 and October 11-13. As shown in the table, 100-year recurrence point rainfall at the SRS is 4.0 inches per hour and 4.9 inches per 3 hours. Thus, the threo-hour rainfalls of 5.2 inches on July 25 and the 4.97 inches on August 22 exceed the 100 year recurrence values. Moreover, the 12-hour rainfall rate on August 22 also exceeded the 100 year value. One-hundred year rainfall maxima for a 48 hour period were exceeded at four measuring sites during October 10-12, including Bush Field.

It may seem that the statistics for maximum rainfalls are in enror because the 1990 rainfalls exceeded the 50 and 100-year recurrence intervals so many times. It should be remembered, however, that we have presented data from 15 gages and for several duration intervals. Thus, the chances of exceeding a recurrence interval are many times greater than if we were considering a single gage and one duration interval. Moreover, since some of the gages are close together the rainfall events are not statistically independent. Thus, if a rainfall extreme is exceeded at one gage it will very likely be exceeded at a nearby gage as well.

The Probable Maximum Precipitation (PMP) is another, more conservative, measure of maximum rainfall. It is defined as the "greatest possible theoretical depth of precipitation for a given duration and drainage area". It is used in cases where structural failure would be disastrous. The PMP is roughly equal to the greatest worldwide rainfall amounts. These are shown in Fig. 21.

The PMP for ten-square miles and one hour is 15.7 inches, and for six hours 31.0 inches. Typically, the six hour 10 square mile PMP is two to nine times that of the six hour 100 year recurrence interval. 
From Figure 9 we can estimate that over 6 inches of rain fell in a ten-square mile area during the August 22 storm. This is just $20 \%$ of the six-hour PMP value of 31.0 inches. Thus, The August 22 storm is well short of the PMP.

As noted above, the total rainfall recorded at the SRS in October 1990 ranged from a minimum of 17.12 to a maximum of 19.05 inches. The previous high for a month at the SRS was 12.34 inches (August 1964). The highest monthly rainfall ever recorded prior to 1990 at Bush Field was 14.00 inches (July 1906) and at the Columbia airport was 16.72 (August 1949). In October of 1990 Bush Field and Columbia reported 14.82 and 11.66 inches of precipitation, respectively. Thus, the October rainfall at the SRS is the largest monthly value ever seen and also exceeds the maximum monthly values at Augusta, $\mathrm{Ga}$ and Columbia, SC.

\section{Summary}

The storms on July 25, and August 22, 1990 caused three-hour rainfalls of 5.2 inches at Building 773-A and 4.97 inches at the Climatology Sitc. These rainfalls are comparable to extreme values recorded at Bush field and the Columbia airport since 1948, namely 4.25 and 5.03 inches respectively. They also exceed the estimated 100-year maximum rainfall rates for the SRS of 4.9 inches.

The August 22 storm exceeded the 100-year recurrence interval for durations of 6 and 12 hours. It exceeded the 50-year recurrence interval for rainfall durations of 24 hours.

The October 10-12 tropical storms Klaus and Marco caused rainfalls at the SRS which ranged from 9.9 inches to 10.2 inches. These values exceeded the expected 100-year maxima of 9.4 inches for a 48 -hour period. The largest 48-hour rainfall for the October 11-12 period was recorded at Bush Field, where 11.15 inches fell 'cetween 7:00 am on October 10 and 7:00 am on October 12.

The October 22-23 storm, when added to other precipitation during the month, produced rainfall amounts over the site of between 17.12 and 19.05 inches. This amount far exceeded the previous monthly maximum of 12.34 inches (August 1964) and made October of 1990 the wettest month ever recorded at the SRS. 
Figure 1: Locations of SRS rain gages.

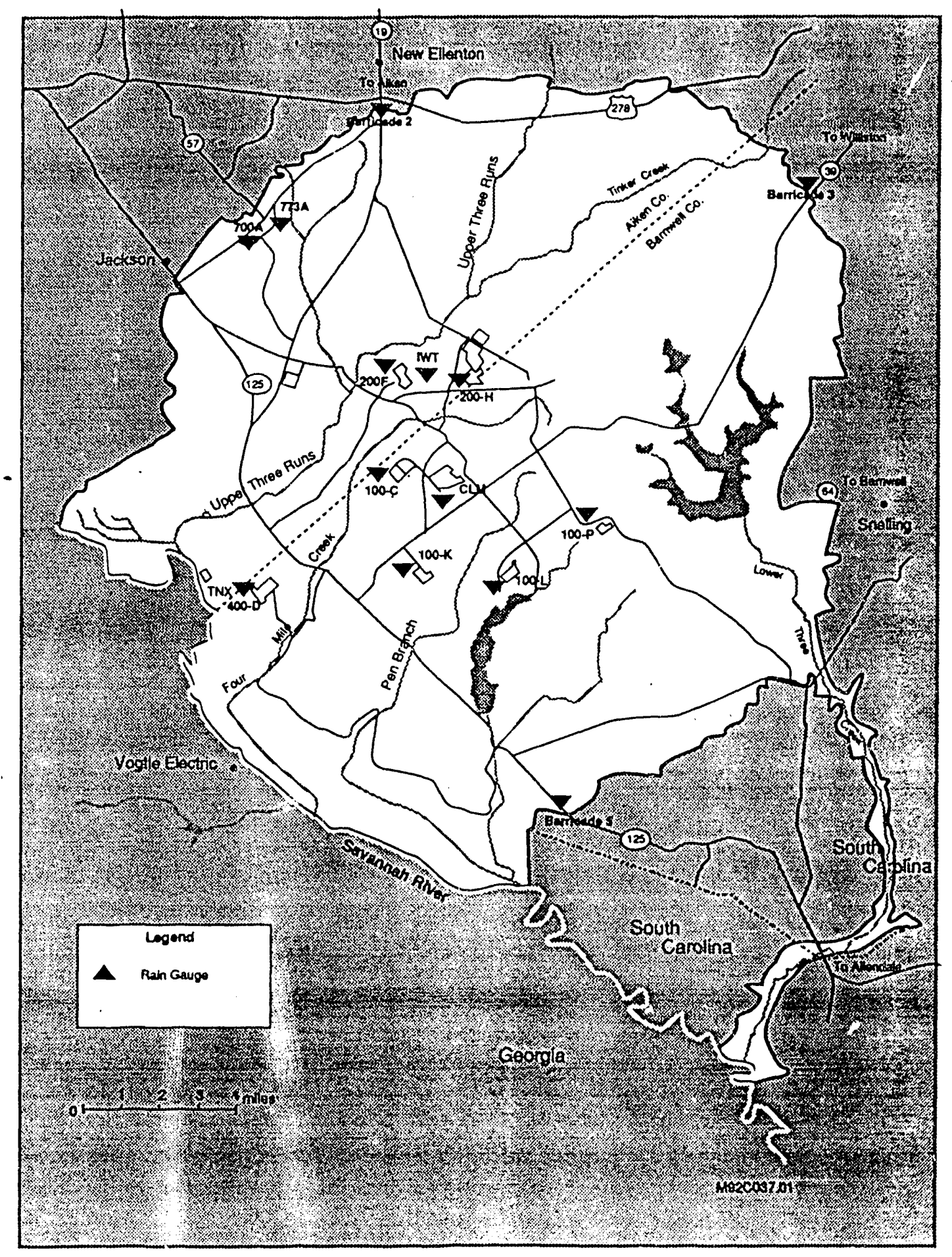




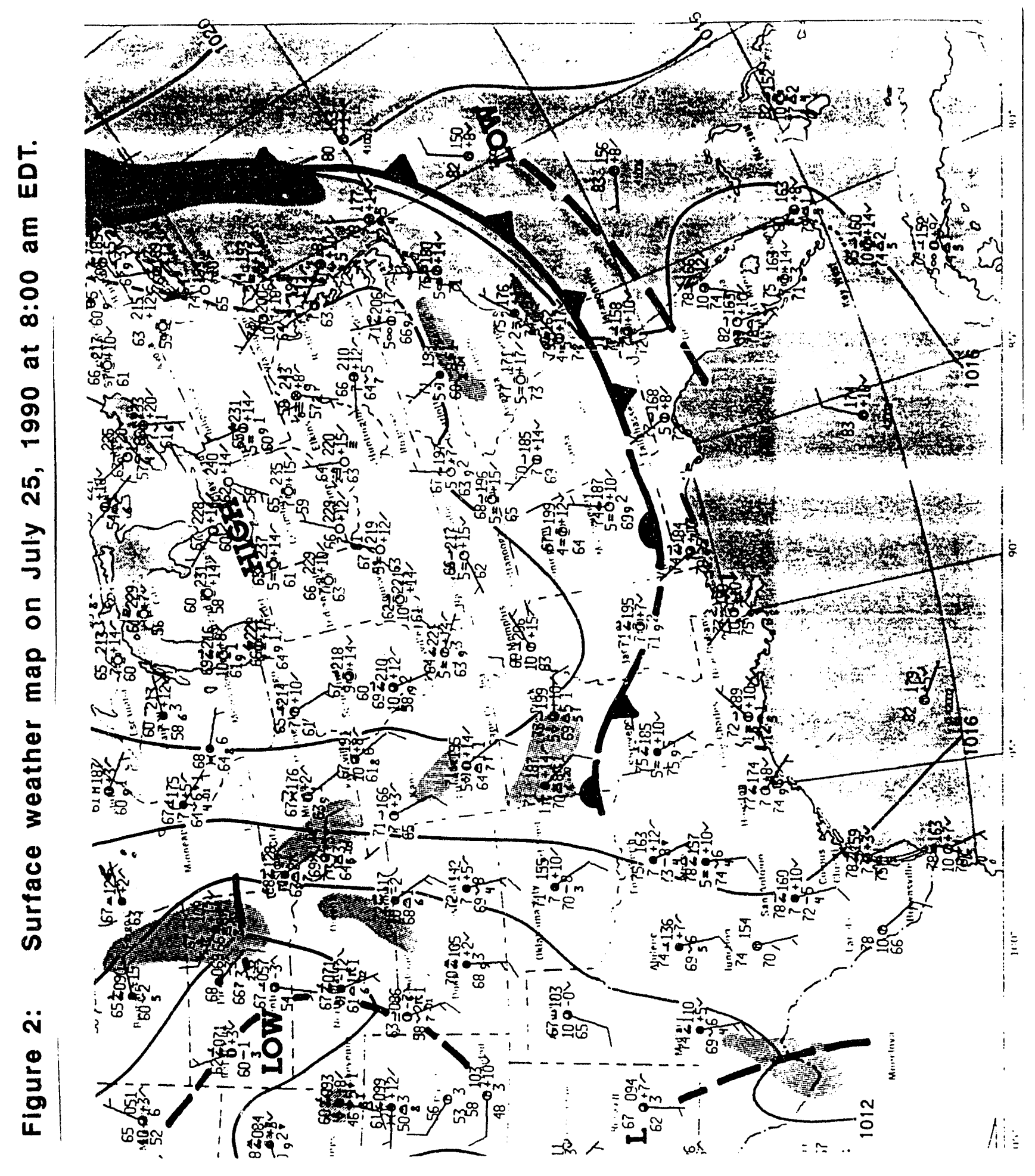




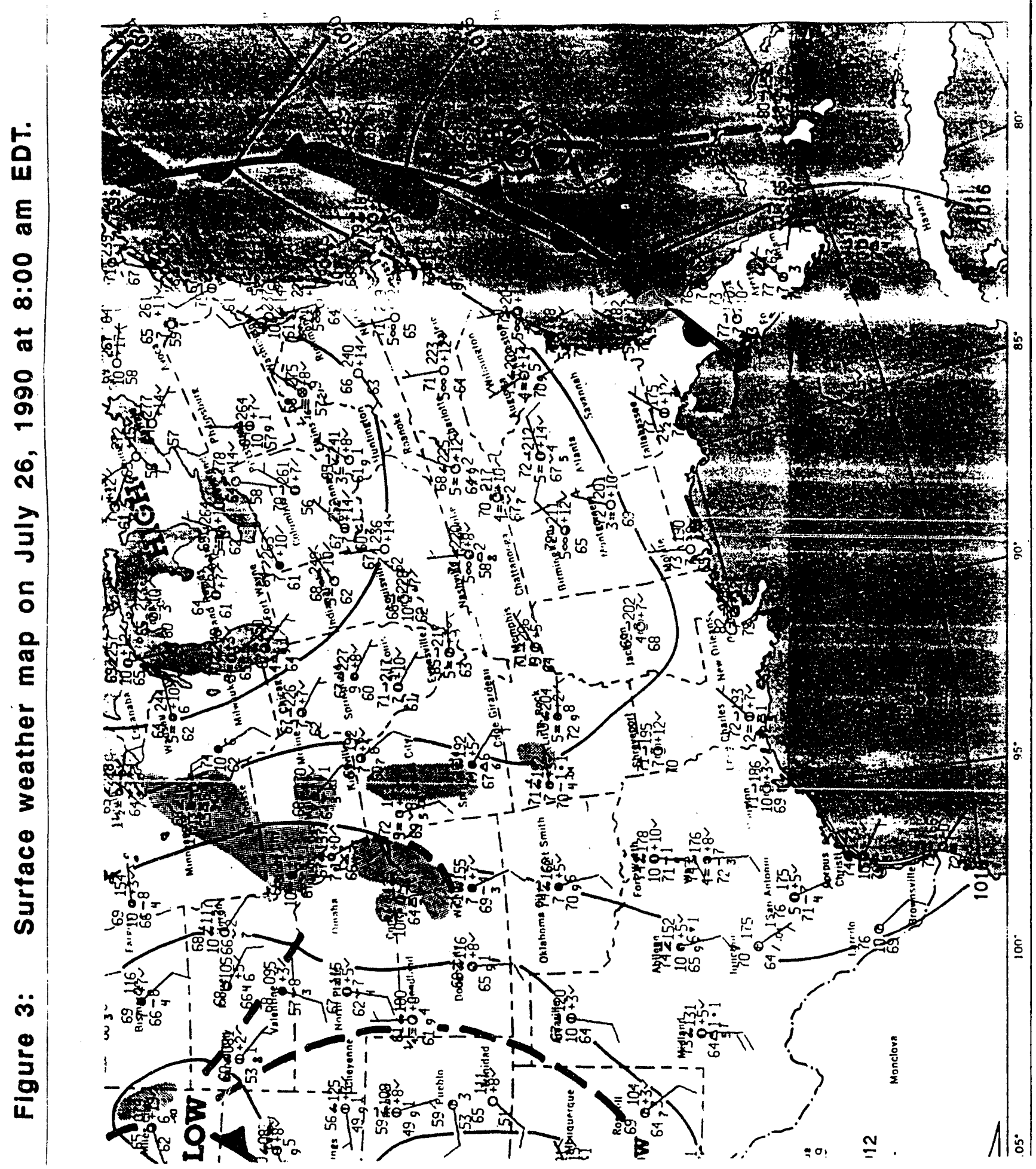


Figure 4: Composite radar summary for 4:00 pm EDT on July 25, 1990. (Reproduced with permission of the WSI Corporation)

NOWRAD image printed by "WX-View" from Robertson software. AGS 20:00(20)GMT 25-JUL-90 NOWRAD COPYRIGHT WSI CORPORATION Weakest ---- Radar Echoes ---- Strongest

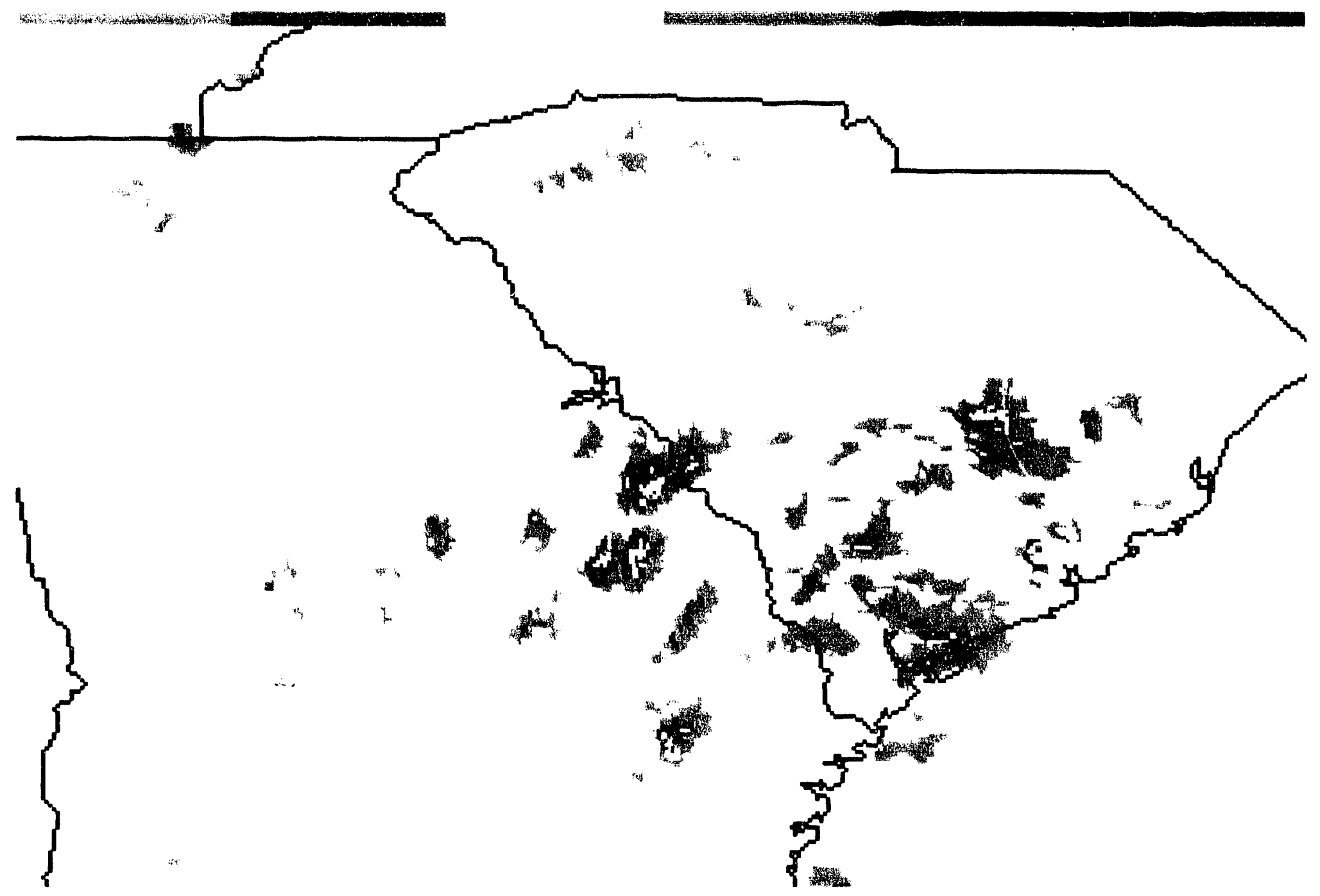


Figure 5: Composite radar summary for 8:00 pm EDT on July 25, 1990. (Reproduced with permission of the WSI Corporation)

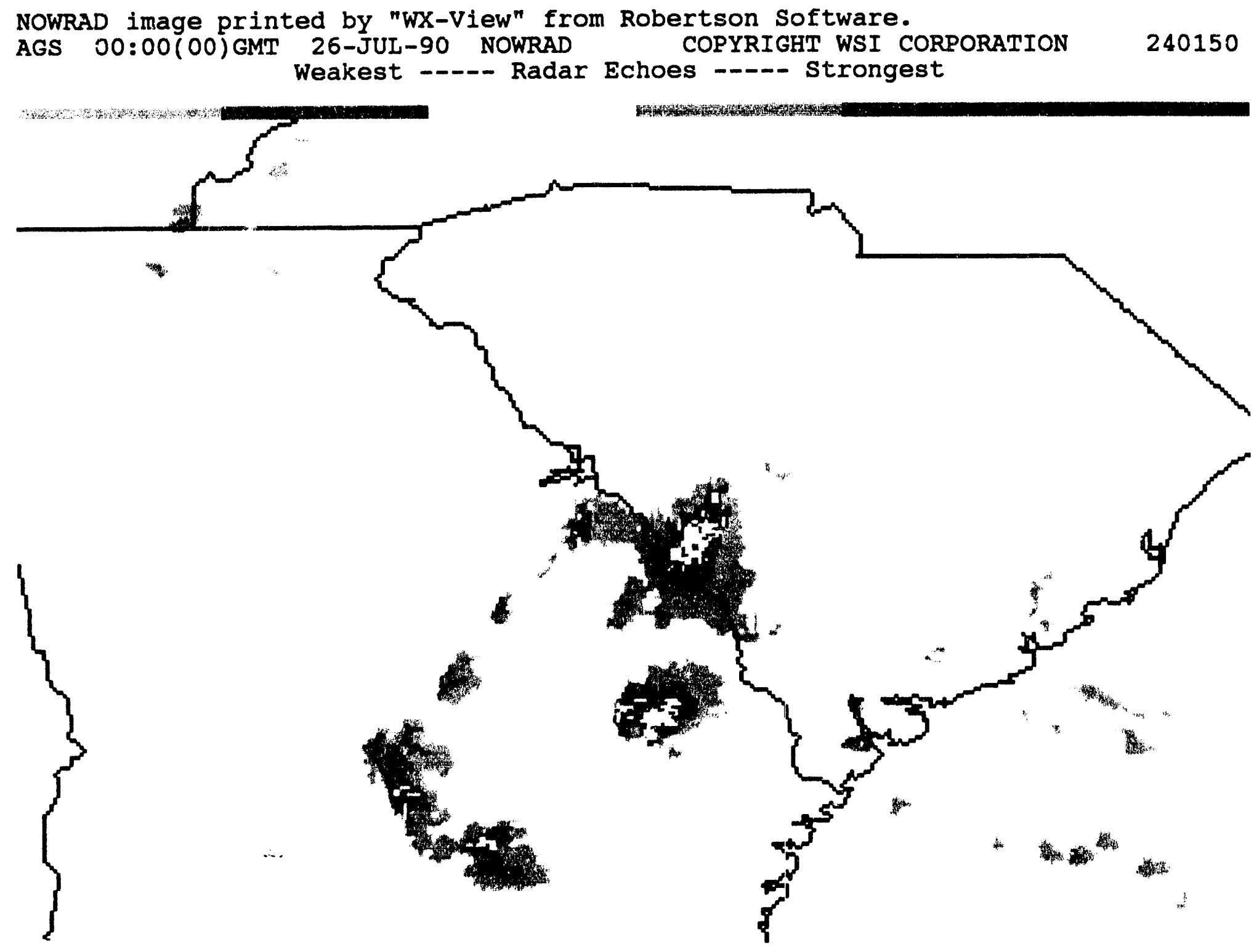


Figure 6: Composite radar summary for 10:00 pm EDT on July 25, 1990. (Reproduced with permission of the WSI Corparation)
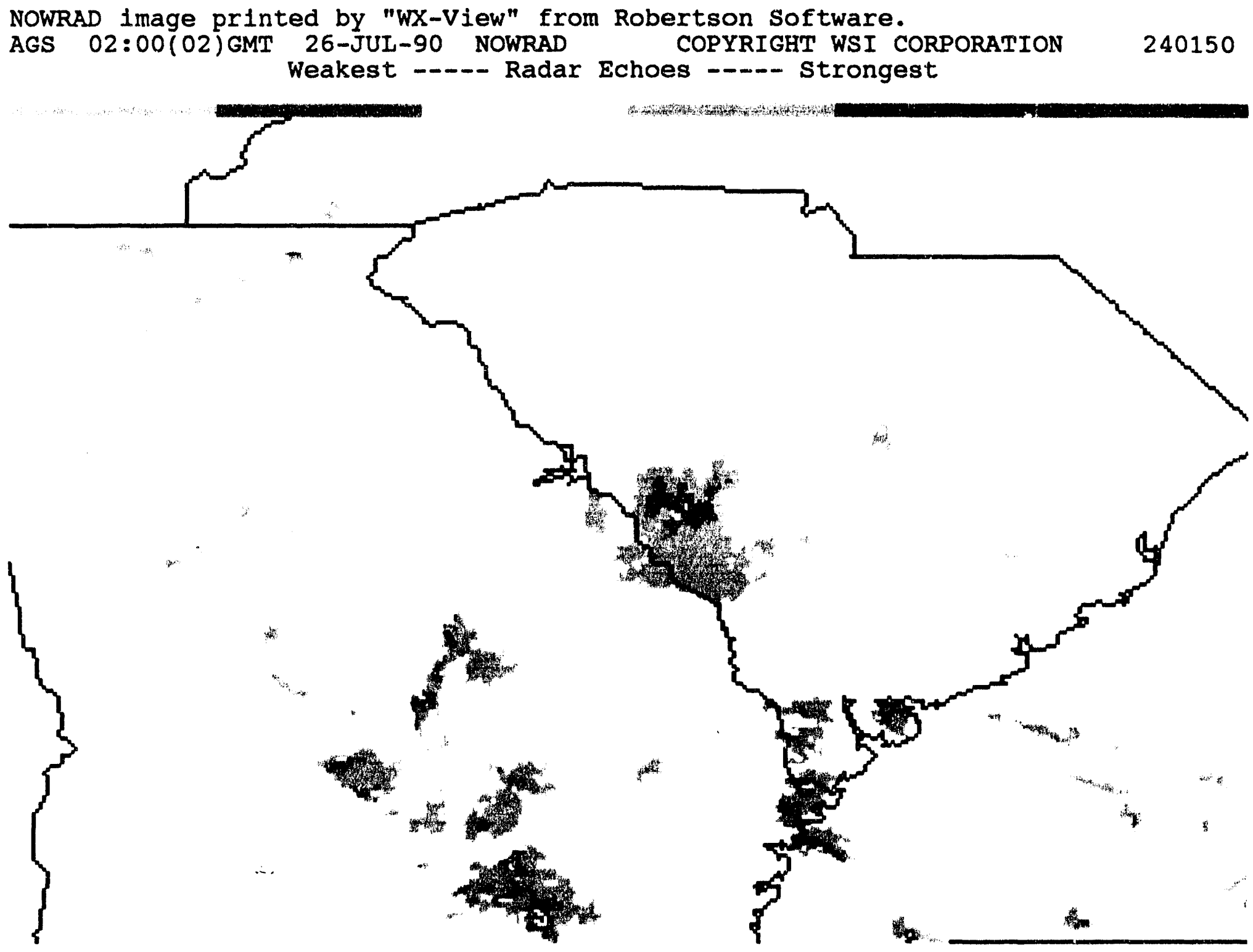


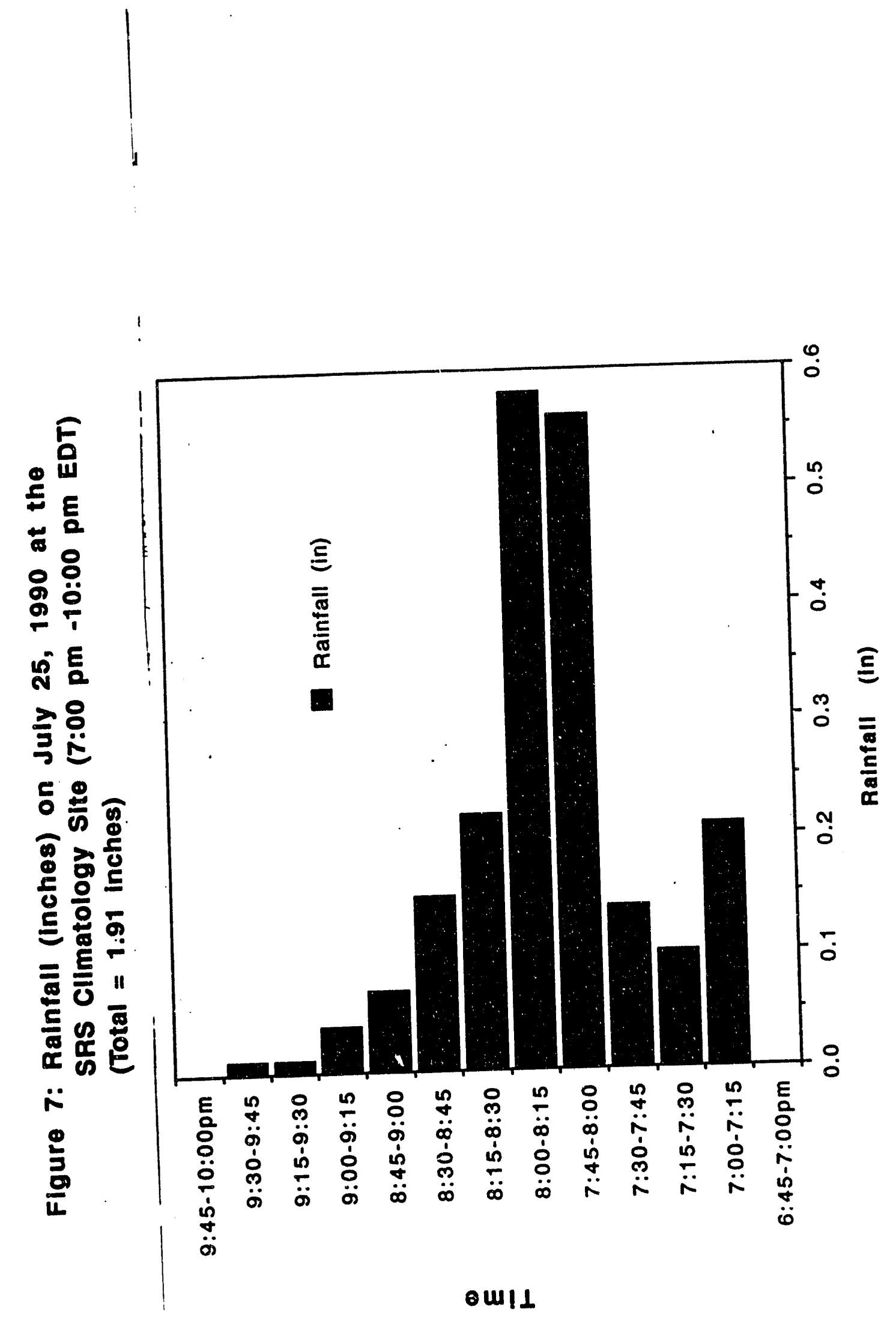


Figure 8: Surface weather nlap on Aug 22, 1990 at 8:00 am EDT.

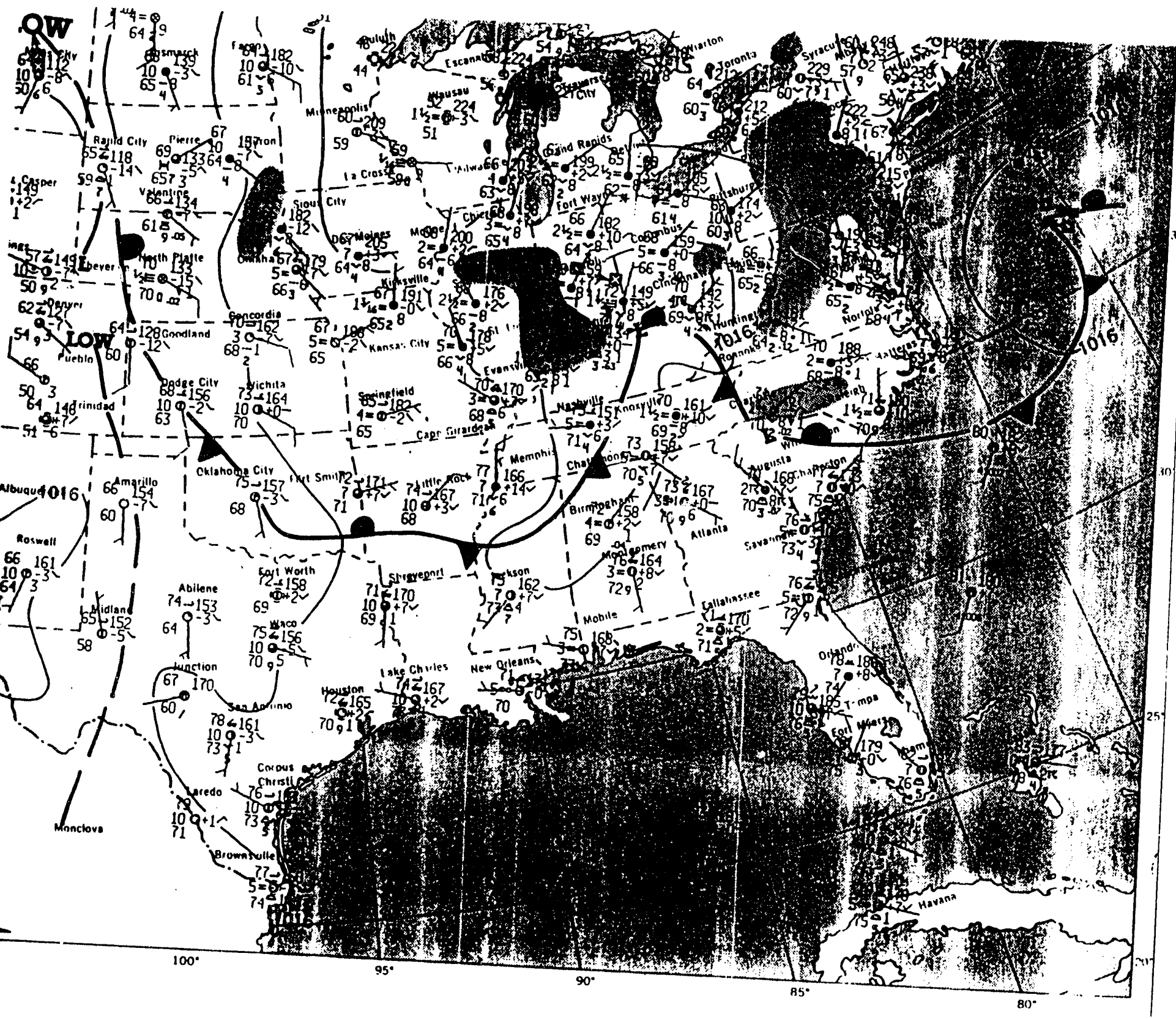


Figure 9: Rainfall in inches from 12:00 am to 5:00 am EDT on Aug 22, 1990.

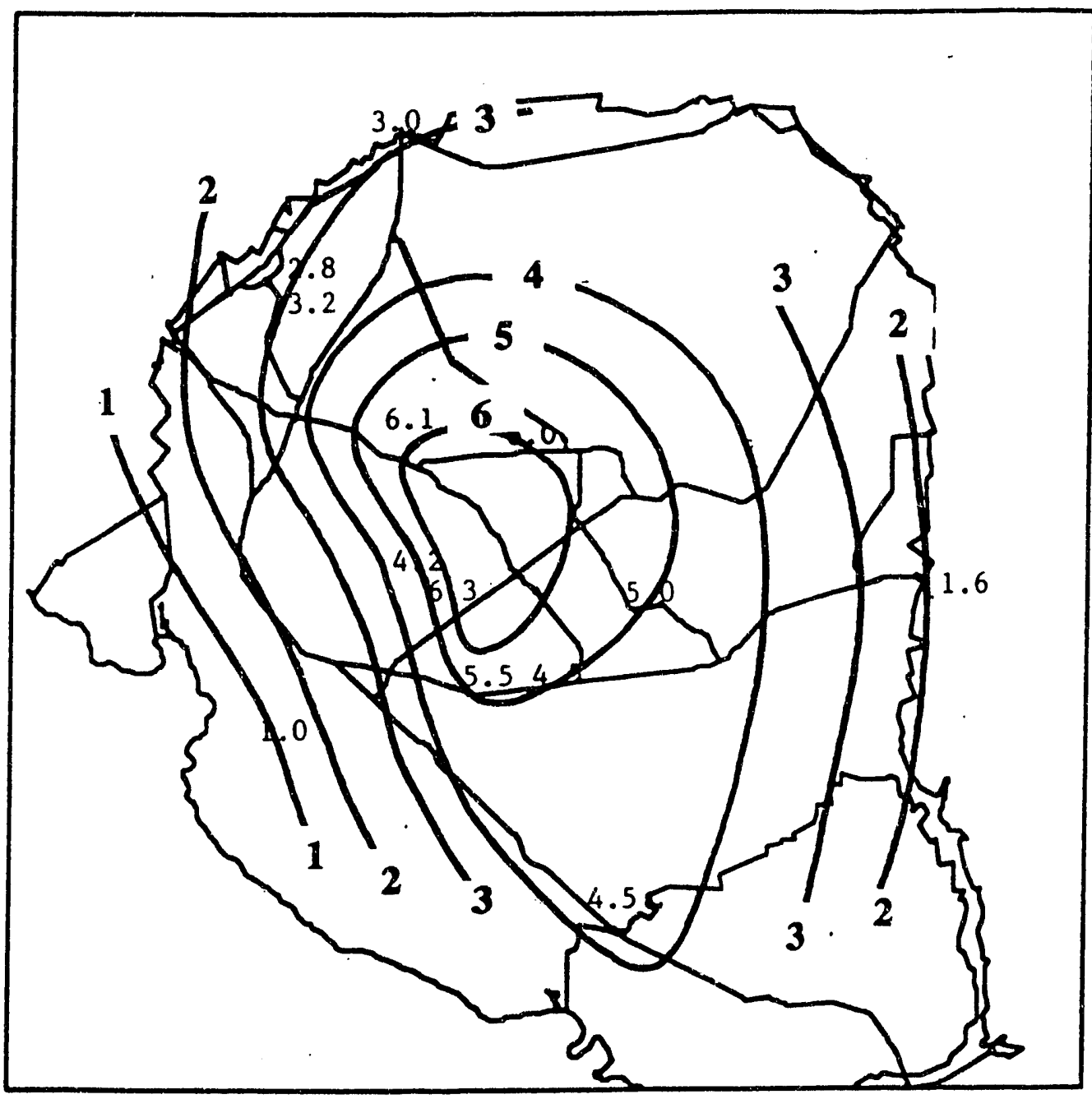




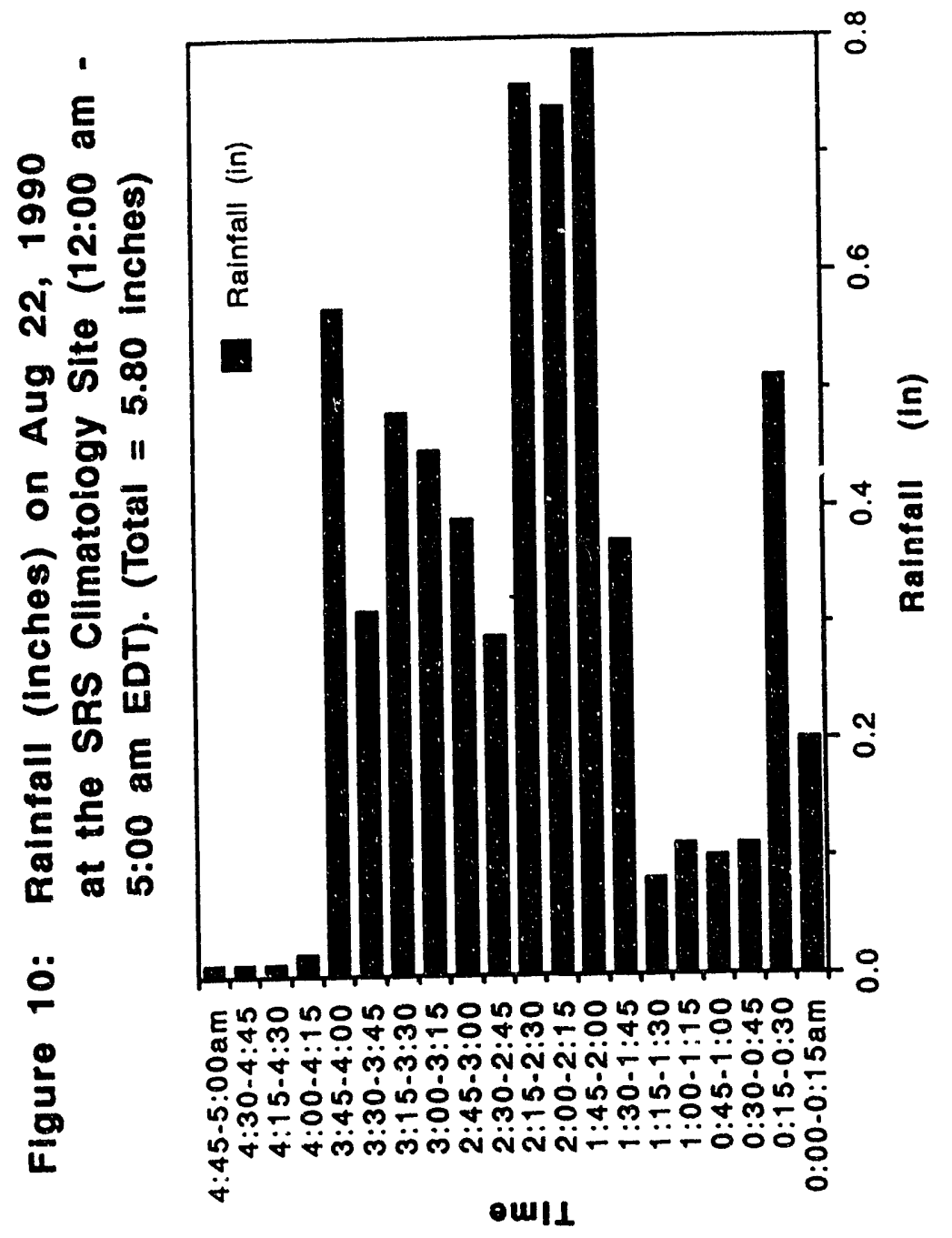


Figure 11: Rainfall in inches from 9:30 am to 12:30 pm EDT on Aug 22, 1990.

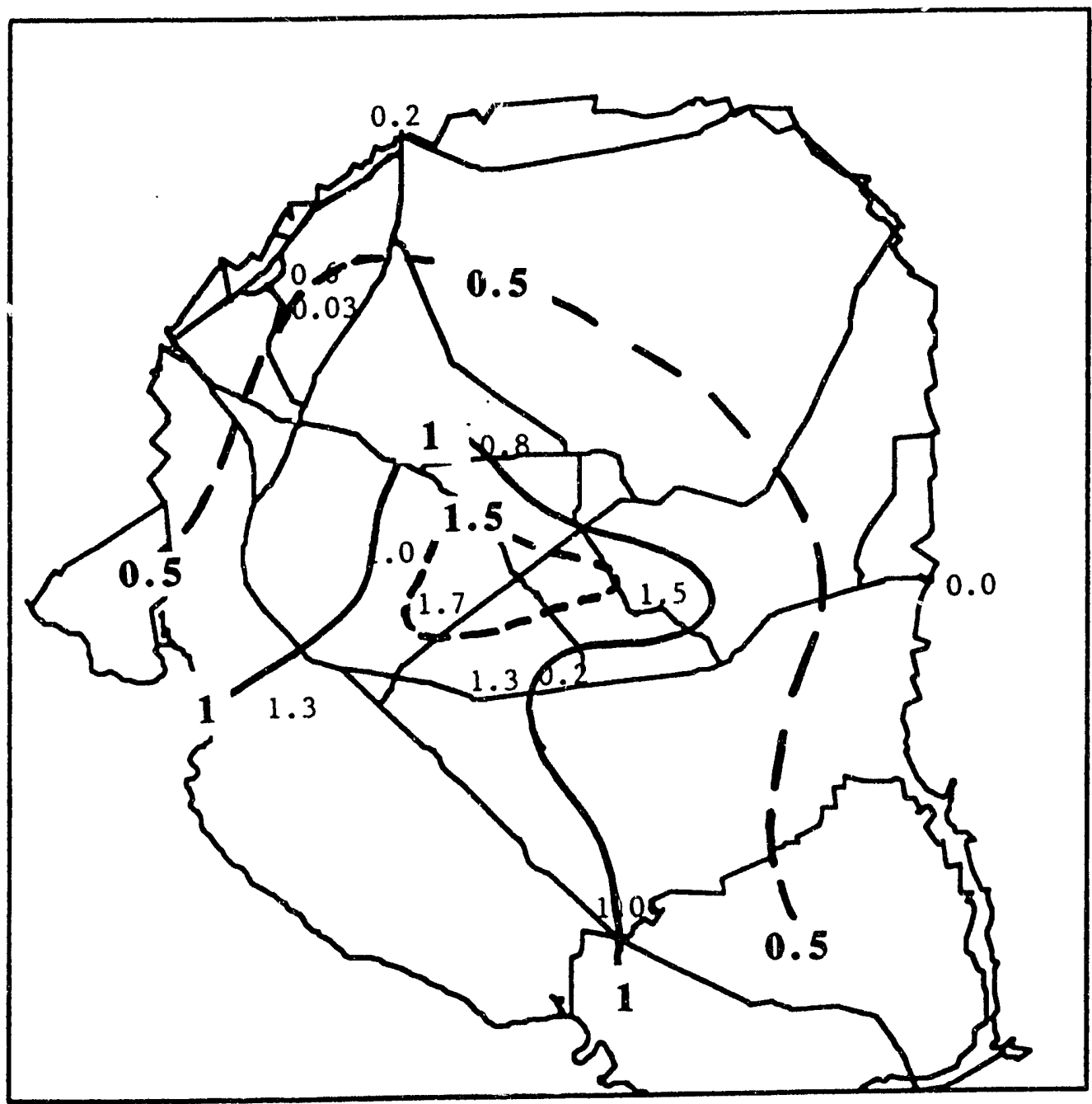




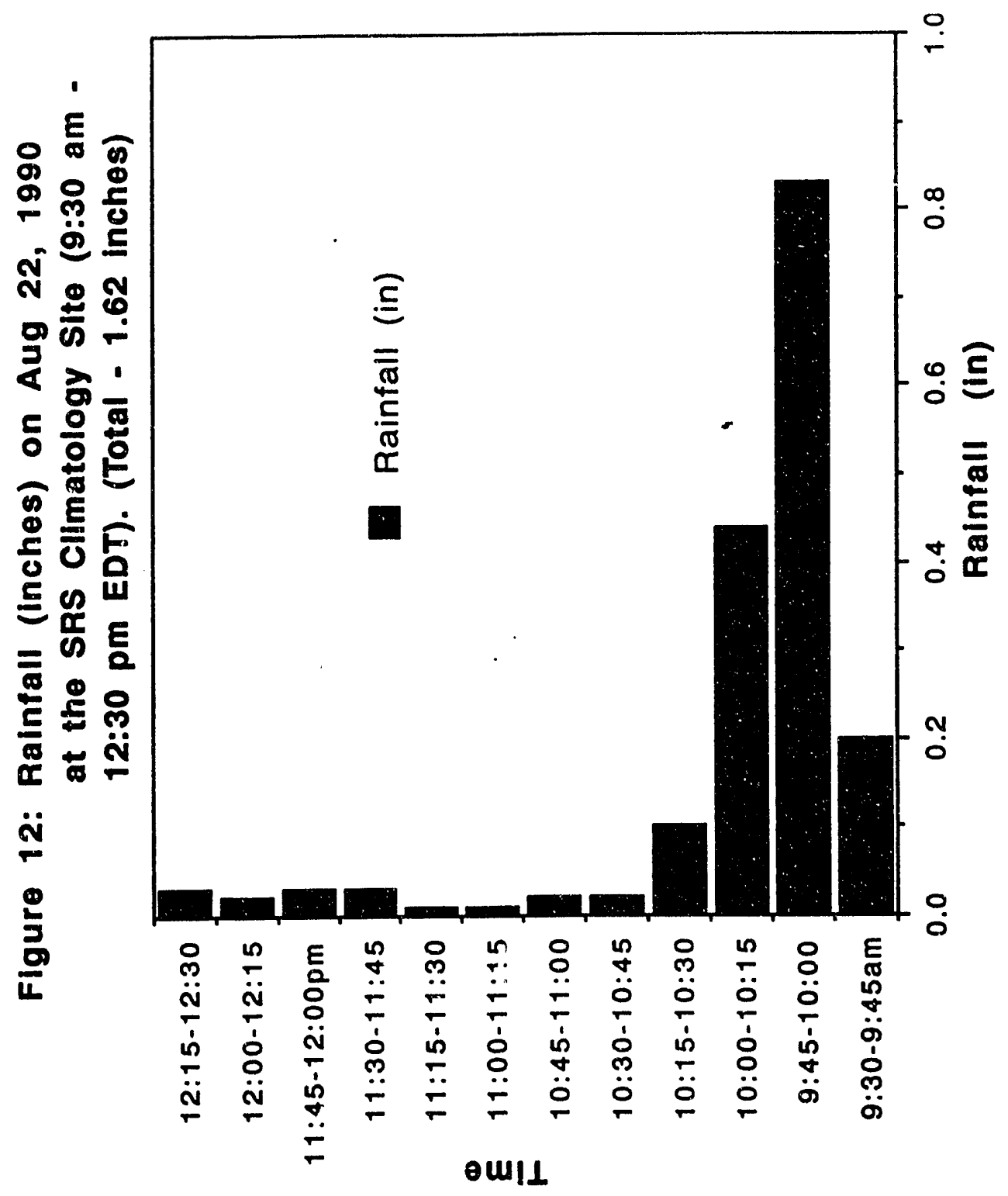


Figure 13: Surface weather map on October 10, 1990 at 8:00 am EDT.

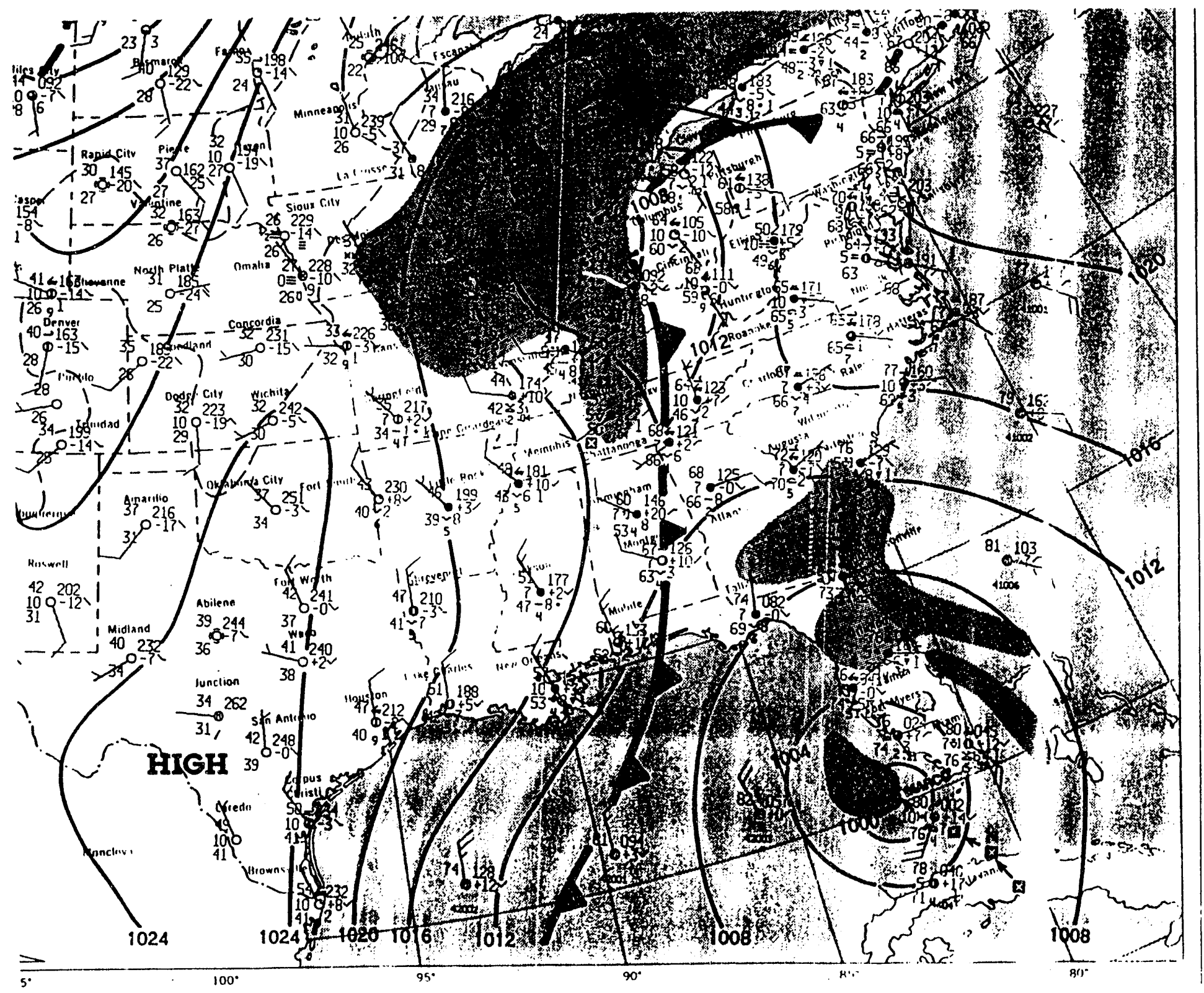


Figure 14: Surface weather Map on October 11, 1990 at 8:00 am EDT.

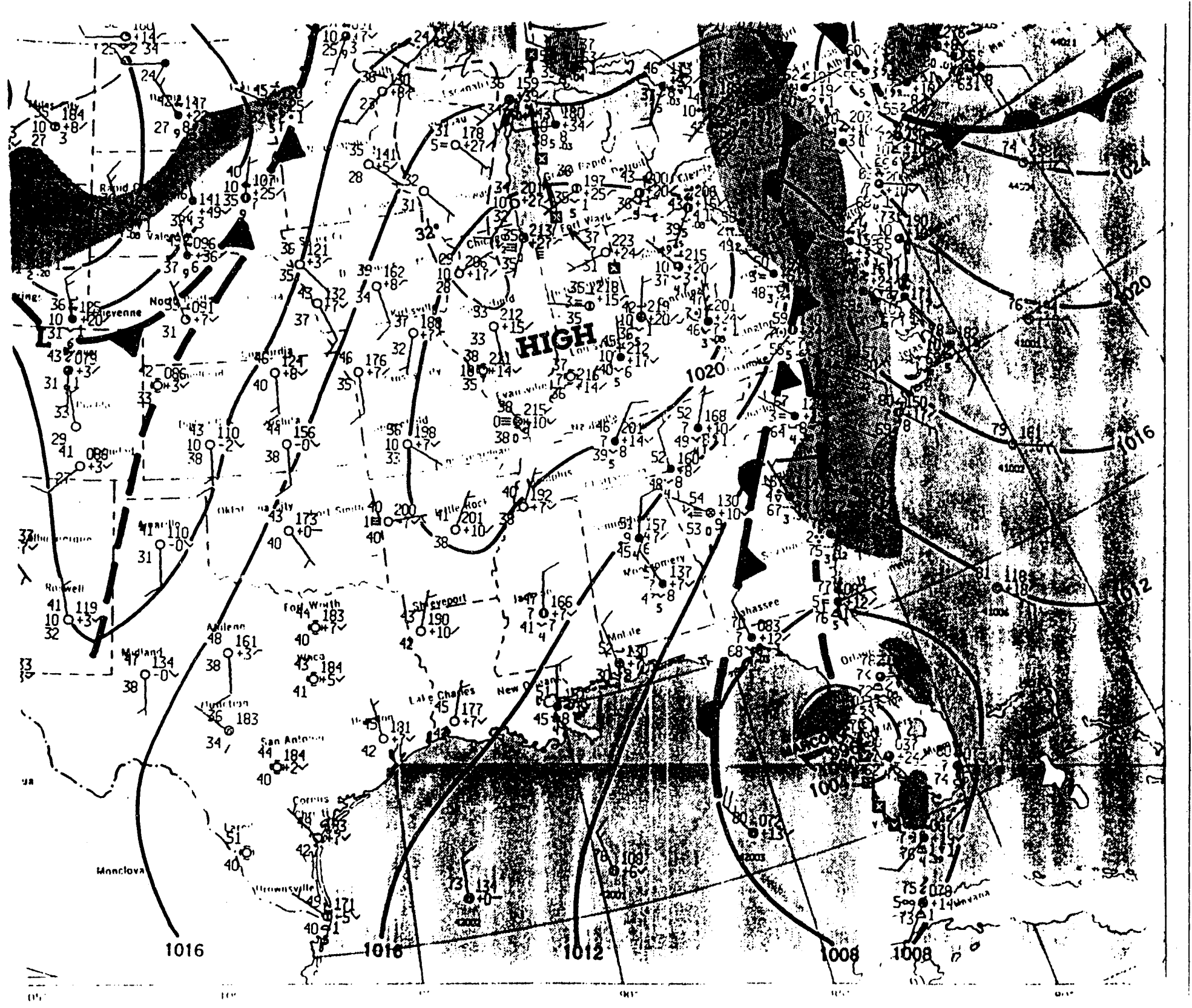


Figure 15: Surface weather Map on October 12, 1990 at 8:00 am EDT.

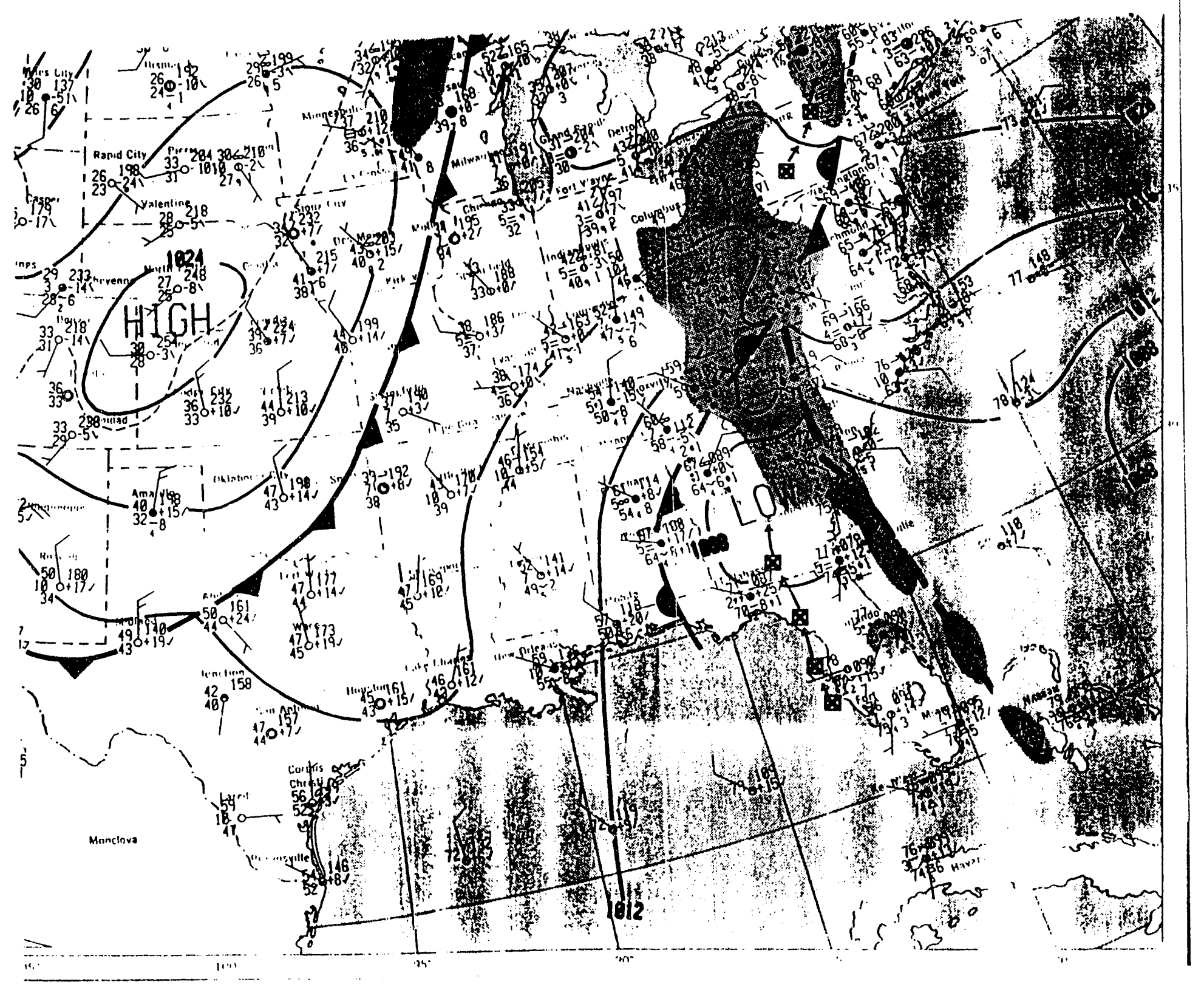




\section{Figure 16: Satellite Infrared Image of the Southeastern United States at 3:00 pm EDT, Oct. 11, 1991.}

SUPSAT image printed by "WX-View" from Robertson Software.

HAT 19:00(19)GMT 11-OCT-90 SUPERSAT COPYRIGHT WSI CORPORATION 00

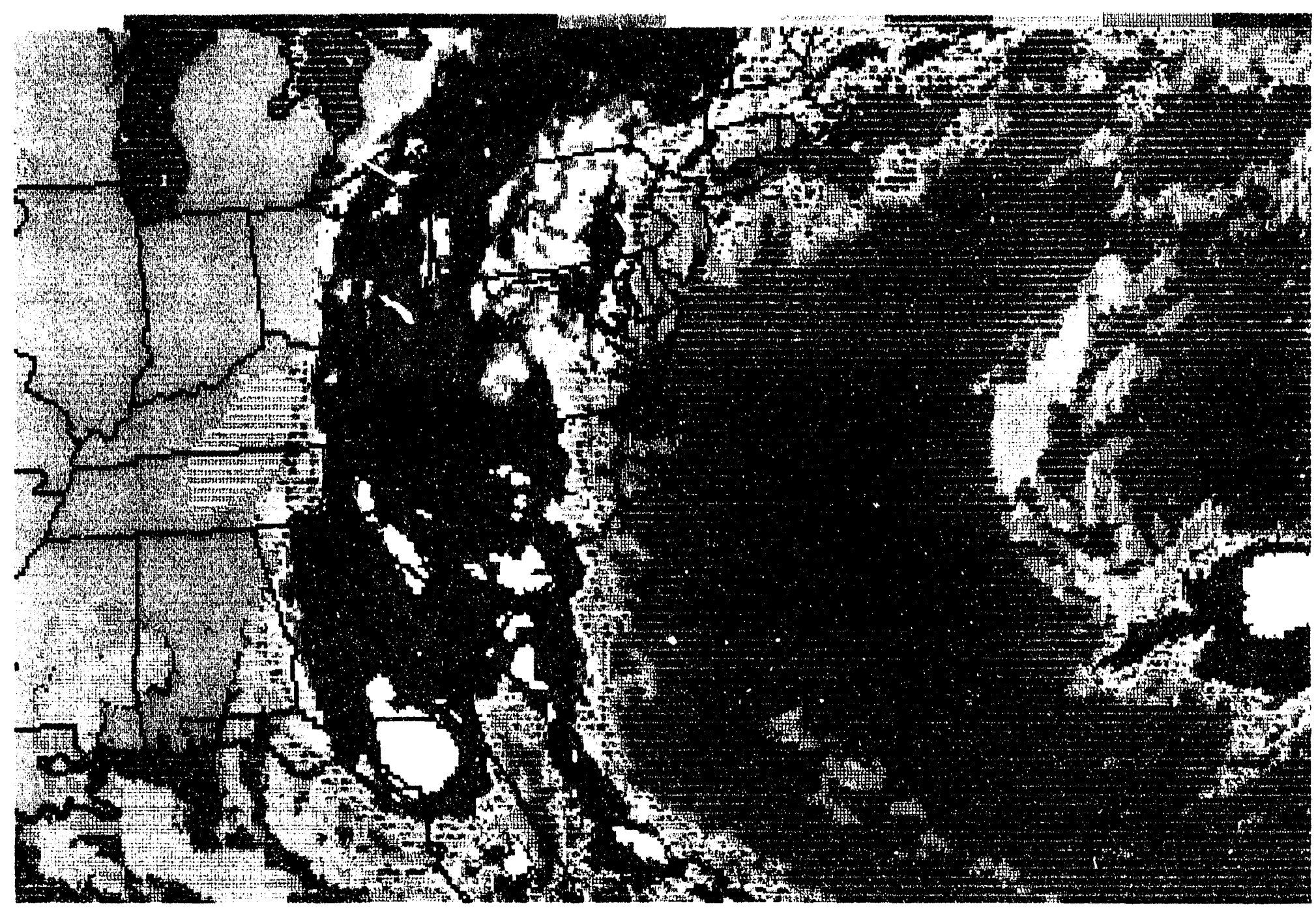




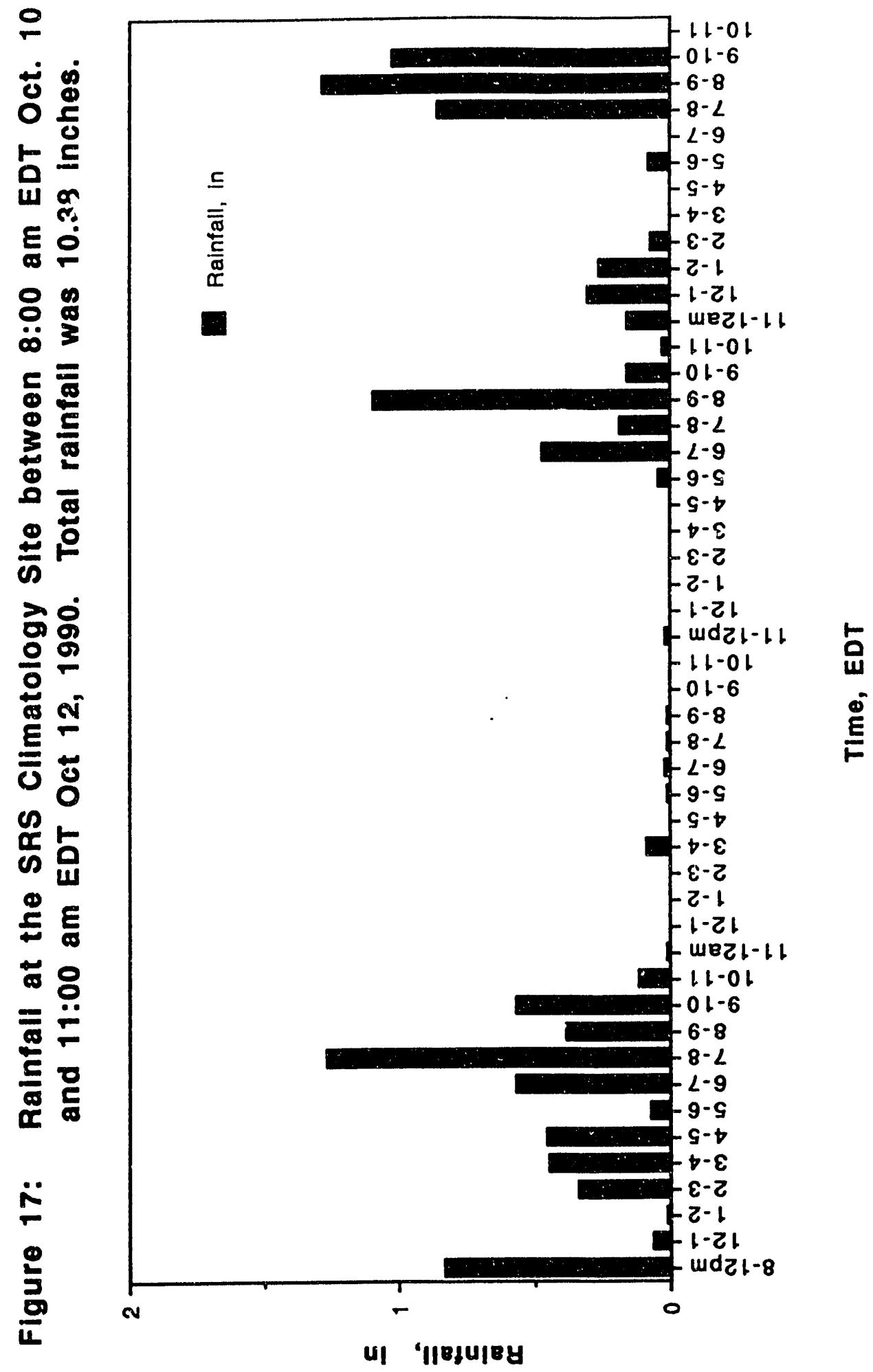


Figure 18: Surface weather Map on October 22, 1990 at 8:00 am EDT.

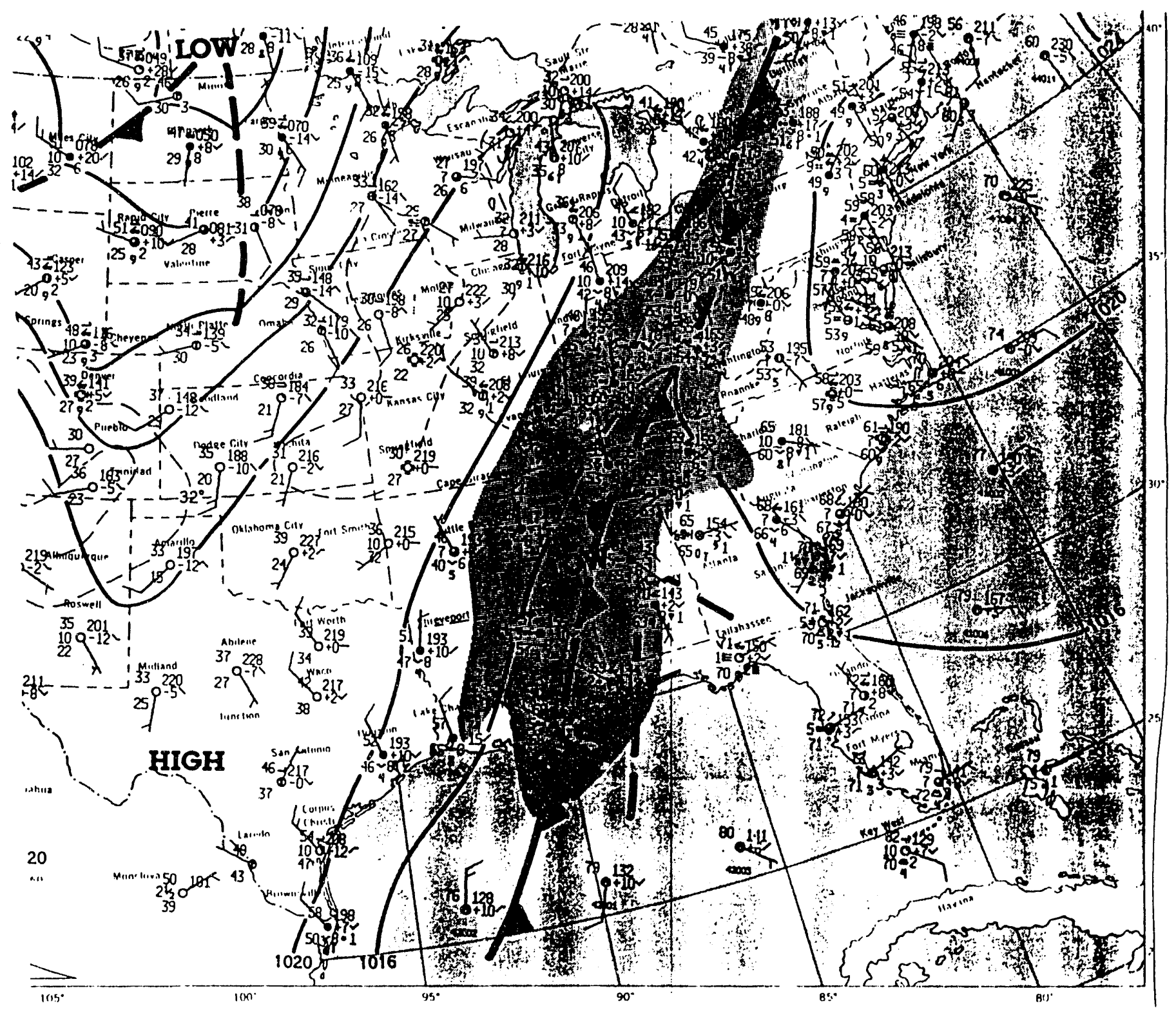


Figure 19: Surface weather Map on October 23, 1990 at 8:00 am EDT.

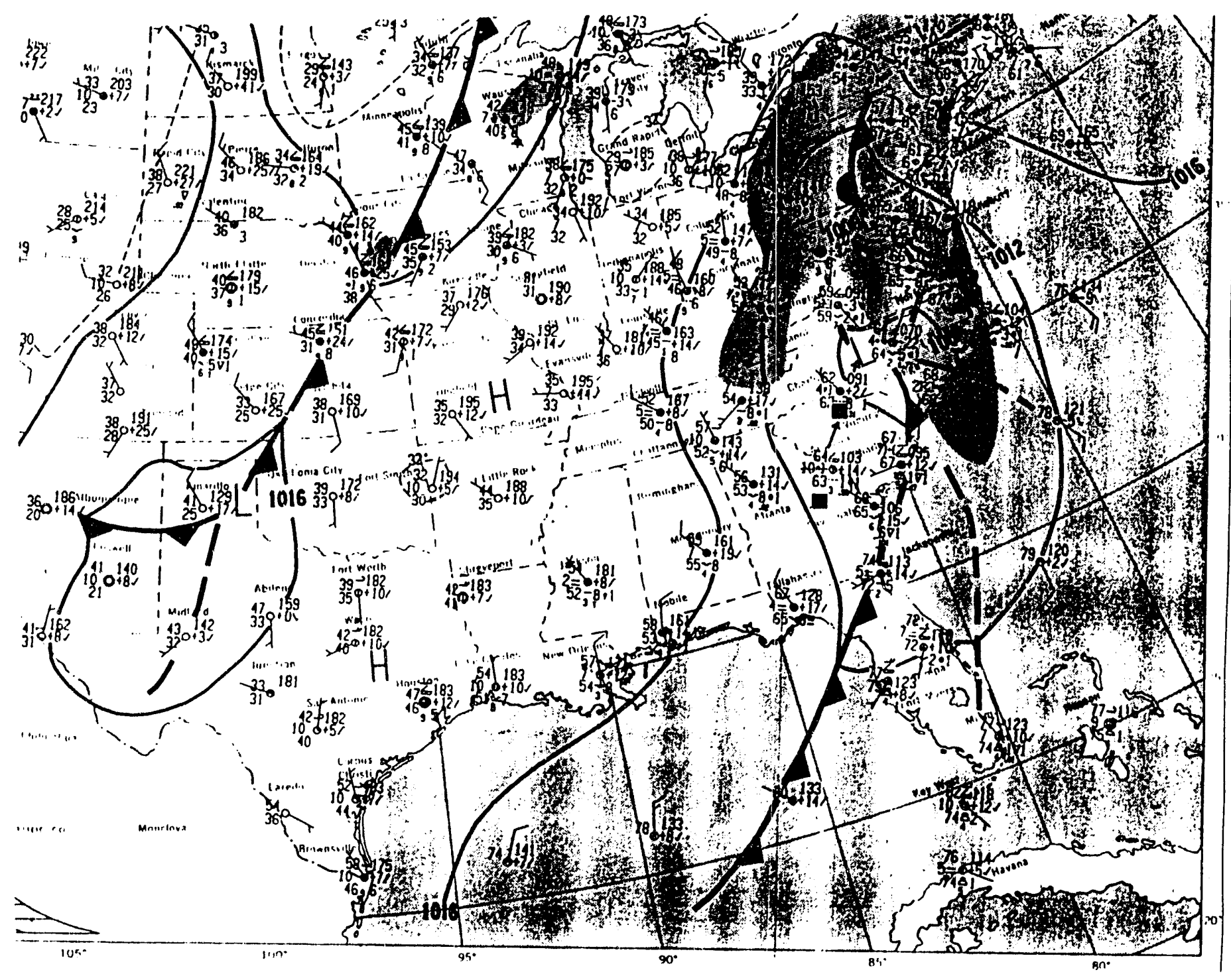


Figure 20: Rainfall (inches) at the SRS Climatology Site between 11:00 pm EDT Oct 22, and 5:00 am EDT Oct 23,1990 . Total rainfall $=3.37$ in.

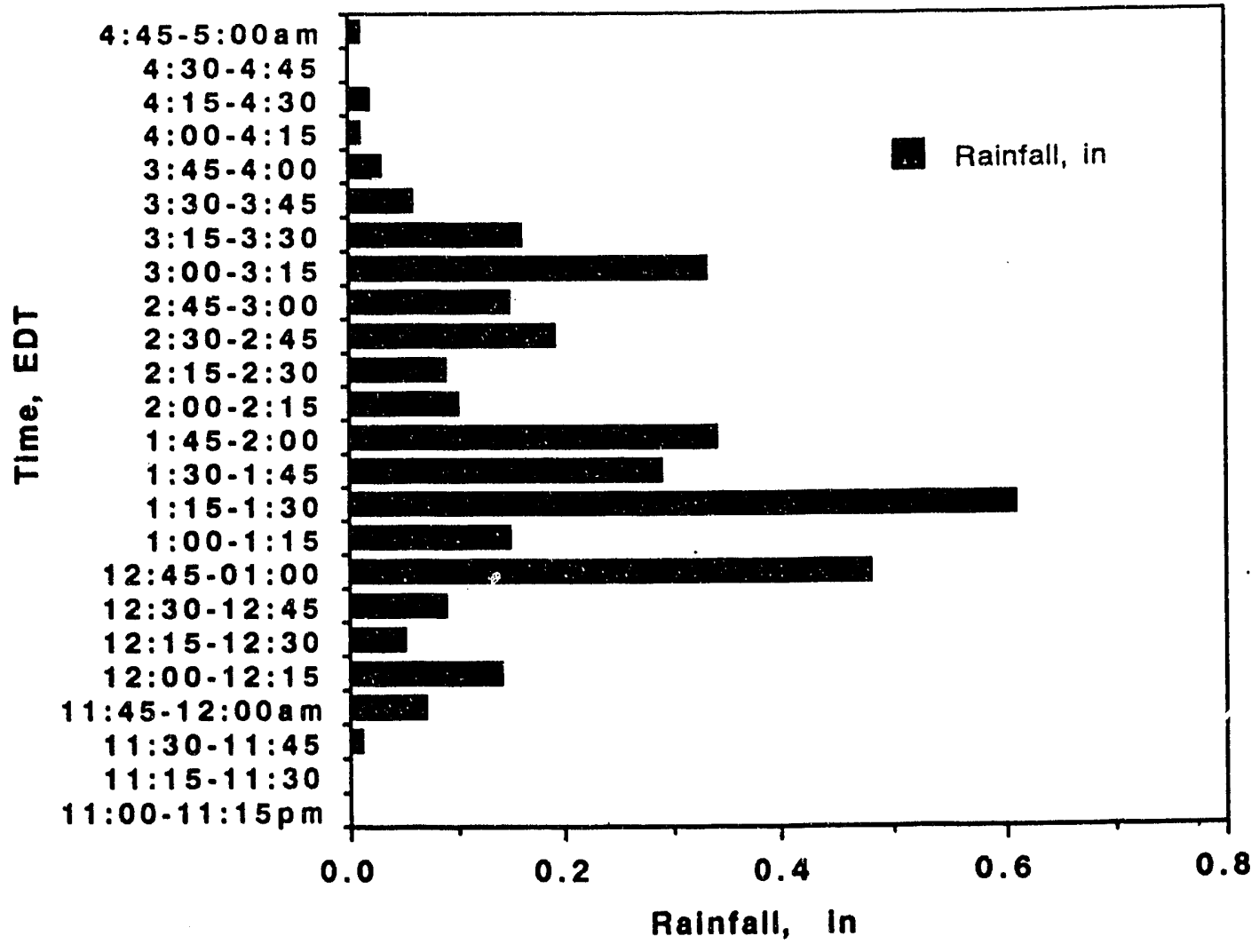



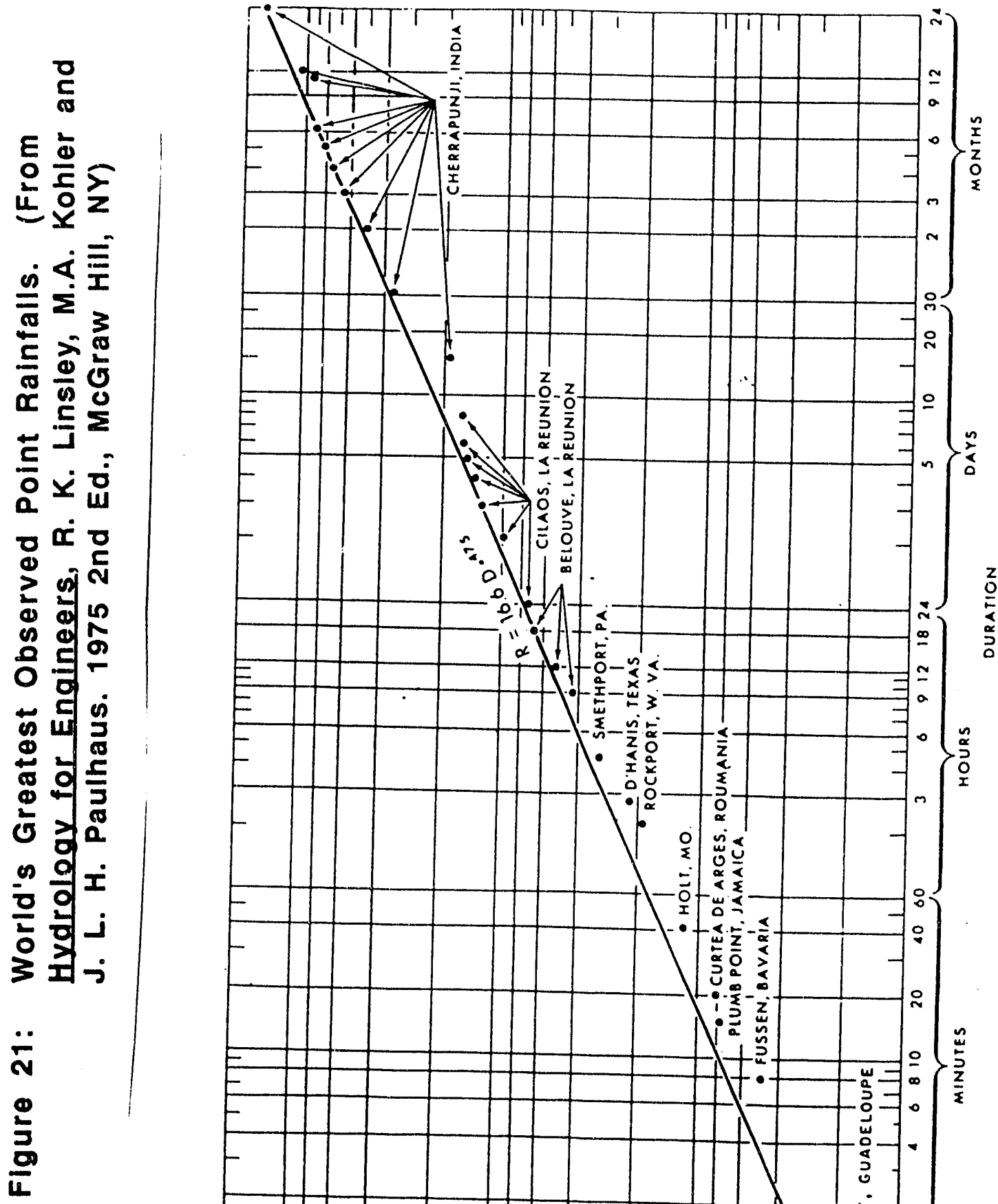


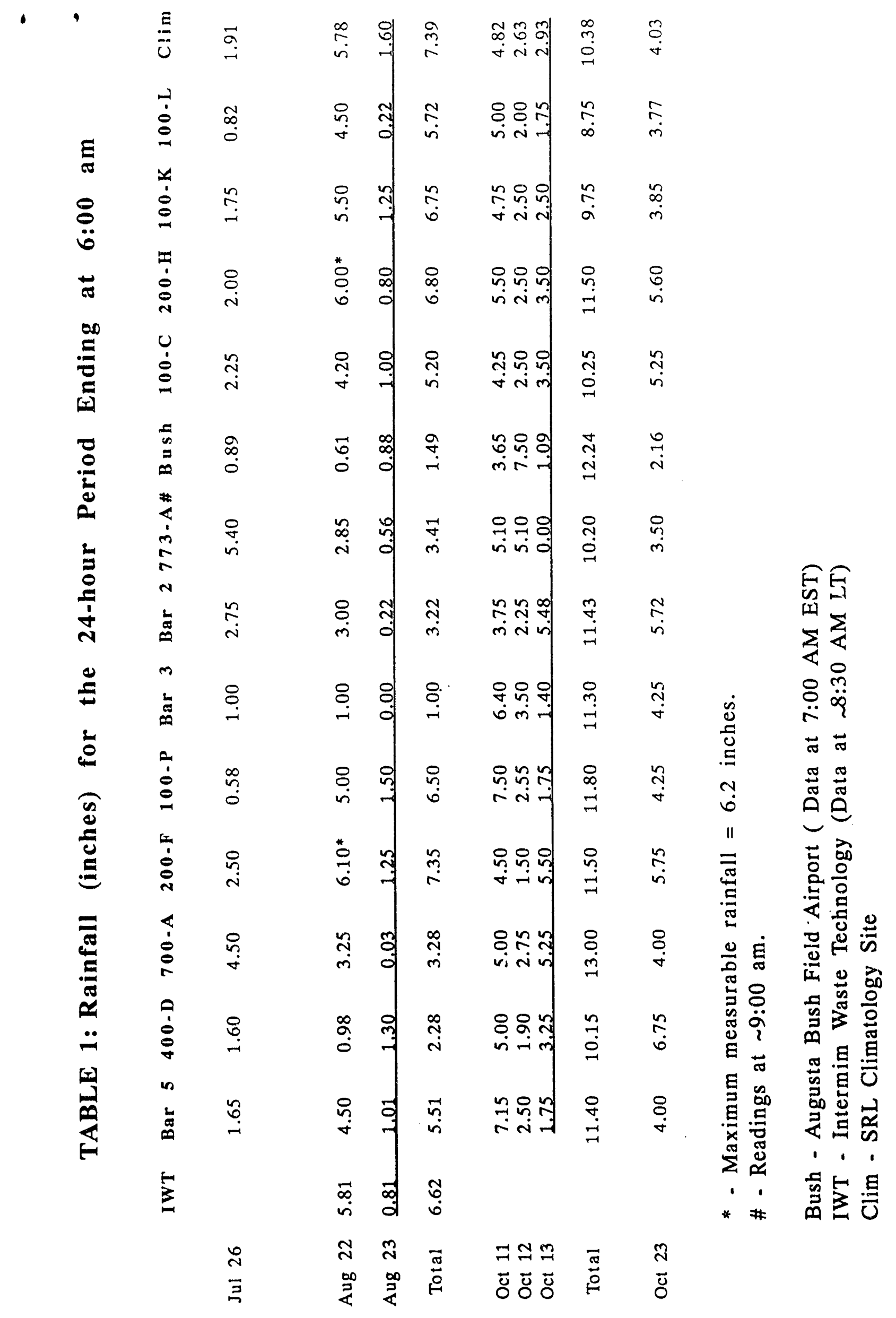


TABLE 2:

\section{AUGUSTA BUSH FIELD AIRPORT RAINFALL EXTREMES}

Period of Record: August 1948 through May 1988

\begin{abstract}
Period
Hours
\end{abstract}

1

3

6

12

24

\section{Days}

3

7

10

14

30

60

90
7.56

8.68

9.26

9.91

12.86

19.84

25.88
Local

Time

1300

1900

1900

1100

2400

Date

$7 / 24 / 86$

9/20/75

9/20/75

$3 / 10 / 67$

$8 / 28 / 64$

$8 / 28 / 64$

$5 / 31 / 81$

$5 / 31 / 81$

$7 / 02 / 50$

$7 / 02 / 50$

7/15/64

7/18/64 
TABLE 3:

\section{COLUMBIA AIRPORT RAINFALL EXTREMES}

Period of Record: August 1948 through June 1988

Period

Hours

1

3

6

12

24

Days

3

7

10

14

30

60

90
8.41

10.22

10.29

14.71

19.30

25.64

33.69
Local

Time

2000

1900

1700

2200

1600
Date

$8 / 18 / 65$

$8 / 18 / 65$

6/15/73

$8 / 16 / 49$

$8 / 16 / 49$

$8 / 14 / 90$

$6 / 15 / 73$

6/13/73

$8 / 14 / 49$

7/29/49

6/18/71

7/18/64 


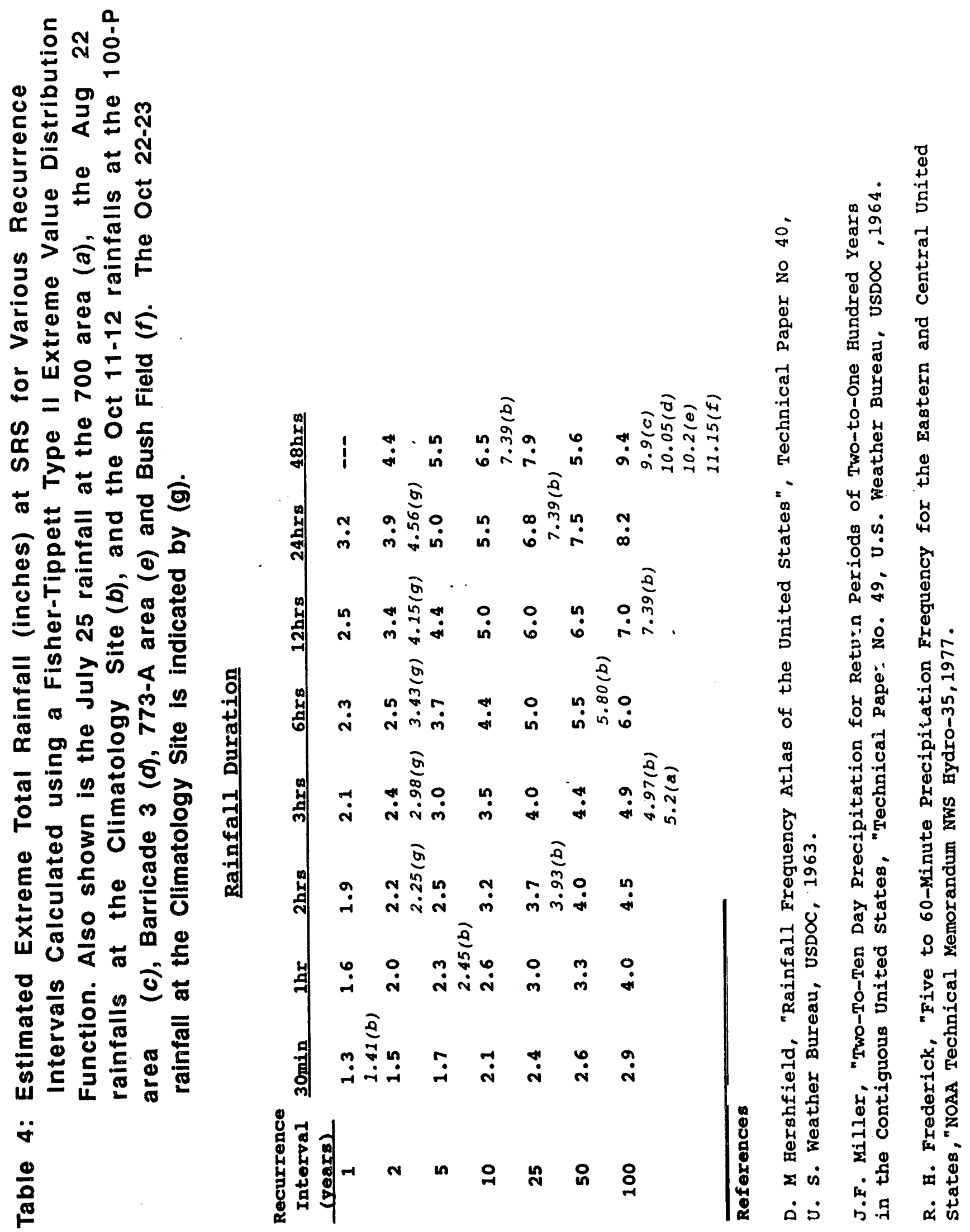



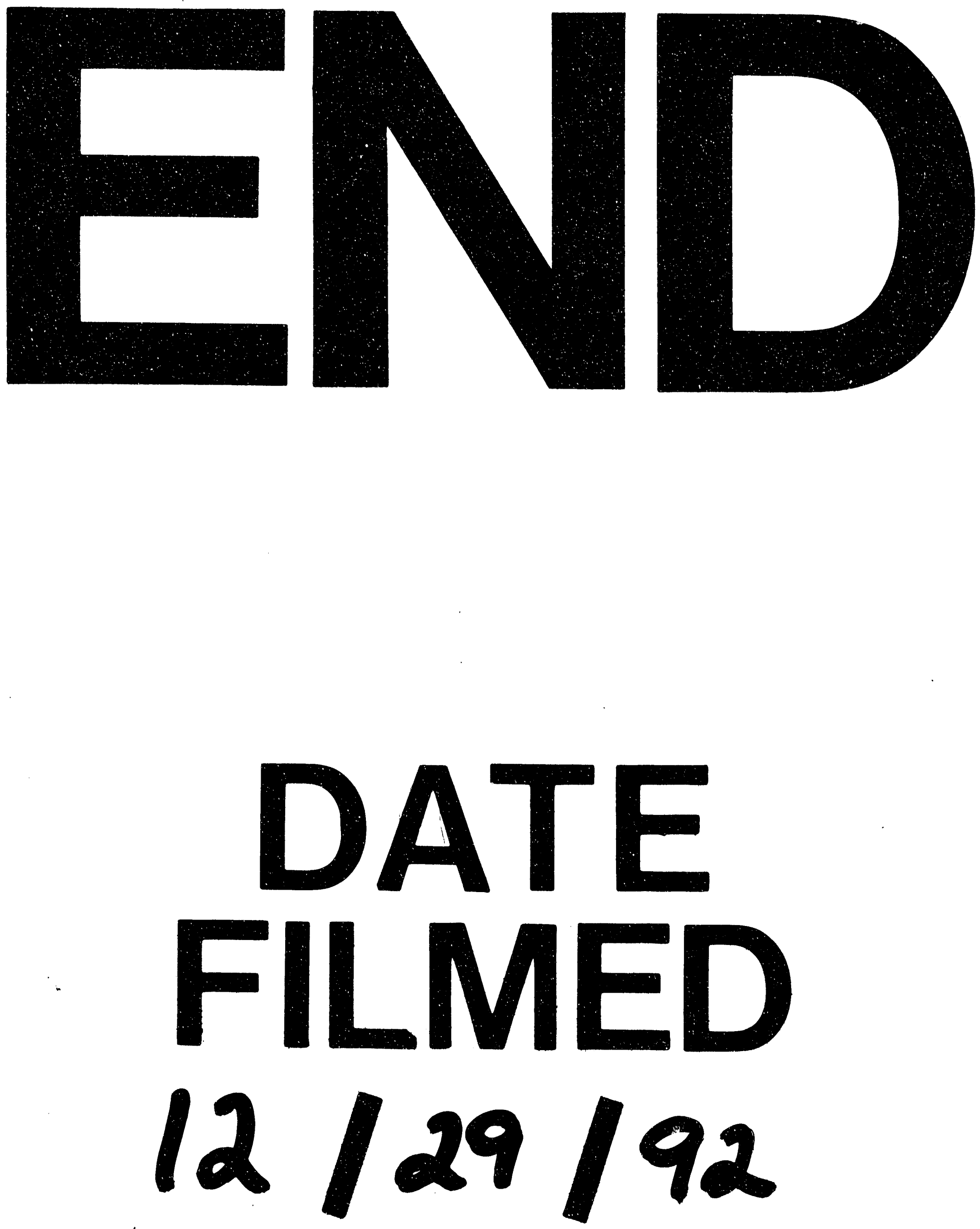

1 
